\title{
Precautionary Hoarding of Liquidity and Inter-Bank Markets: Evidence from the Sub-prime Crisis*
}

\author{
Viral V. Acharya \\ Ouarda Merrouche \\ London Business School, NYU-Stern, \\ Bank of England \\ CEPR and NBER
}

First Draft: September 20, 2008

This Draft: July 3, 2009

\begin{abstract}
Using data on the behavior of large settlement banks in the UK and the Sterling Money Markets before and during the sub-prime crisis of 2007-08, we provide evidence of precautionary hoarding of liquidity and its effect on inter-bank borrowing rates. Our evidence consists of three pieces. First, we document that liquidity holdings of the large settlement banks in the UK experienced on average a $30 \%$ increase in the period immediately following 9th August, 2007, the widely accepted date of money-market "freeze" during the sub-prime crisis. Second, we show that following this structural break, bank liquidity had a precautionary nature in that it rose on calendar days predicted to have a large amount of fluctuations in payment and settlements activity and more so for banks that made larger losses during the crisis. Third, using the payment and settlements activity as an instrument, we establish a causal effect of bank liquidity on overnight inter-bank rates, in both secured and unsecured markets, an effect that is virtually absent in the period before the crisis. Importantly, precautionary hoardings by some settlement banks raised lending rates for all settlement banks, suggestive of a contagion-style systemic risk operating through inter-bank rates. Finally, variability in overnight inter-bank rates appears to have affected rates and volumes in household as well as corporate lending.
\end{abstract}

JEL:

Keywords: cash, cash hoarding, inter-bank lending, financial crisis, contagion, systemic risk

*A part of this paper was completed while Acharya was a Senior Houblon-Norman Fellow at the Bank of England (July and August, 2008). This paper reflects the authors' own opinion and not necessarily those of the Bank of England. Acharya is also grateful for the support of BSI Gamma Foundation. Authors are grateful to seminar participants at the Bangor Business School, Bank of England, BSI Gamma Foundation's September 2008 Conference in Zurich, the CREDIT Conference of September 2008 in Venice, the Euronext conference on liquidity in Amsterdam 2009 and the World Bank. We also thank Rachel Bracken and Liz Tregear for help with collecting the data. All errors remain our own. Contact: vacharya@stern.nyu.edu and ouarda.merrouche@bankofengland.co.uk 


\section{Introduction}

The financial crisis of 2007-2009 has highlighted the important role played by money markets (in other words, inter-bank markets) in shuffling liquidity around the banking system. Globally, these markets experienced severe stress starting with the 9th of August, 2007. On this date, BNP Paribas suspended withdrawals from some of its hedge funds invested in sub-prime mortgagebacked securities due to the inability to mark these assets to market. The result was a freeze in the market for asset-backed commercial paper (ABCP), which caused rollover problems for structured investment vehicles (SIV's) and conduits set up by banks as off-balance sheet vehicles for liquidity and regulatory arbitrage purposes. As the ABCP liquidity dried up, banks took assets from SIV's and conduits back on their balance sheets.1 The resulting uncertainty - about the extent of such assets that banks would have to take back on balance sheets, the magnitude of losses banks faced, and whether they had enough capital to bear these losses - affected not just capital markets but also the inter-bank market for borrowing and lending.

Inter-bank markets are generally the private lender-of-last-resort for banks' short-term liquidity needs. Hence, lack of adequate liquidity flows through these markets have the potential to substantially impair real and financial sectors. If liquidity does not get channeled through the banking system to its most efficient use, then intermediation to households and corporations could stagnate. For instance, central banks' transmission mechanism for monetary policy could be rendered less effective if its liquidity provisions get trapped on bank balance-sheets instead of lubricating the flow of credit amongst banks. In turn, central banks may be forced to resort to emergency lending operations - perhaps at overly attractive terms, against risky collateral, and to parts of the banking sector not generally accommodated in its operations (as has been witnessed through a series of liquidity facilities created by the New York Federal Reserve, the Bank of England, the European Central Bank, and other central banks during the crisis). While such an outcome has its share of moral-hazard concerns, it is also accompanied by the misfortune of laying the burden of monitoring and (at least some) credit-risk management, away from peer-based inter-bank system on to central bank balance-sheet.

Our paper is an attempt to understand some of these effects by examining the behavior of inter-bank markets during the crisis period of 2007-2008. We hypothesize and confirm a precautionary motive to liquidity hoarding by banks during this period ${ }^{2}$ and investigate the causal effect of such precautionary hoardings on inter-bank rates and other lending rates in the economy. Our broad conclusion is that events unfolding since August 9, 2007 had the effect of increasing the funding risk of banks, in response to which banks hoarded liquidity. This raised the opportunity cost to banks of giving up their liquidity to provide insurance to other banks in the inter-bank market. Hence, inter-bank lending rates rose for both secured and unsecured lending with spillover effects on bank lending rates to the rest of the economy.

We focus on the Sterling Money Markets before and during the sub-prime crisis, specifically

\footnotetext{
${ }^{1}$ This was either due to reputational reasons or due to liquidity and credit guarantees that sponsoring banks had contractually agreed to while setting up the SIV's and conduits. See Acharya, Suarez and Schnabl (2009).

${ }^{2}$ Such a motive and its effect on markets and the economy has been mentioned often. See, for example, Financial Times (FT) 12 August 2007: "Scramble for cash reflects fears for system"; FT 26 March 2008: "Hoarding by banks stokes fear over crisis"; FT 19 May 2008: "Loans to banks limited despite market thawing". As was put succinctly in a quote by Marco Annunziata, chief economist at UniCredit bank: "It is unclear to what extent hoarding of liquidity reflects a genuine need to stem rising losses, and to what extent it reflects an extremely precautionary behavior driven by high uncertainty."
} 
from January 2007 till the end of November 2008. Our choice of the Sterling markets is driven primarily by the fact that the Bank of England (BoE) monetary policy framework offers an attractive way of measuring a bank's overnight liquidity as its reserves with the BoE. As we explain in Section 2, the remuneration offered by the BoE on these reserves implies that it is optimal for banks to park their liquidity in the form of these reserves $3^{3}$ We construct an aggregate measure of daily overnight liquidity held by the large, settlement banks. ${ }^{4}$

As our first piece of evidence, we show that aggregate bank liquidity experienced a significant upward jump upon the onset of the sub-prime crisis (see Figure 1). Based on econometric tests for structural breaks, aggregate liquidity experienced a $25 \%$ increase in the period immediately starting 9th August, 2007, and a further 15\% increase around 13th March, 2008 (the revelation of severe funding problems and ultimately collapse of Bear Stearns) $5^{5}$

As our second piece of evidence, we show that this build up of bank liquidity was precautionary in nature. First, we verify that banks hold more liquidity on days with greater volume of payments and settlements activity, argued to be days with also greater uncertainty in liquidity needs (Furfine, 2000). Such days are to an extent predictable in that there tend to be significant calendar effects due to holidays and end of quarter days (among others) that cause artificial bunching of several days' or weeks' settlement activity. In particular, the response of bank liquidity to payment and settlement activity is non-existent in the pre-crisis period.

Next, we employ the bank-level variation in liquidity reserves, funding risk and economic performance during the crisis. We find that banks with greater reliance on wholesale funding and (eventually) made greater losses during the crisis, both in terms of recorded accounting losses as well as declines in equity prices, hoarded more liquidity. Further, these banks also held more liquidity in response to payment and settlement activity 6 We conclude that liquidity hoarding occurred at banks in a significant measure due to their own funding or solvency concerns, and not just due to the general lack of funding.

In our third piece of evidence, we study the effect of bank liquidity on interest rates in the economy, inter-bank rates as well as other lending rates. First, we look at spread of the inter-bank rates to Bank of England's policy rate (in order to subsume any step-variations induced by policy changes). We obtain overnight secured rates, based on the UK government's

\footnotetext{
${ }^{3}$ In contrast, the Federal Reserve in the United States did not pay interest on reserves until October 2008.

${ }^{4}$ We exclude the two foreign banks since their liquidity kept in the form of the BoE reserves underestimates their overall liquidity, possibly substantially. We also exclude one bank which became a settlement bank in the middle of our sample period. And, we also study "total liquidity" that includes the bank collateral as under "doubleduty" this can be employed for intra-day borrowing from the BoE. This collateral which is held in fulfillment of prudential requirements cannot be used to borrow overnight on the market. Our results are qualitatively similar for overnight liquidity as well as total liquidity.

${ }^{5}$ While 9th August, 2007 is recognized by most as a crucial breakpoint, anecdotal evidence also supports the second breakpoint of 13th March, 2008. See, for example, FT 9 April 2008: "UK banks seek higher borrowing facilities", and FT 10 April 2008: "UK banks seek more BoE borrowing", which noted that "UK banks asked to increase sharply the reserves they hold on deposit at the Bank this month to the highest ever level amid concerns that the instability of the banking system could suddenly leave them desperate for cash. They fear another bank crisis - akin to the collapse of US investment bank Bear Stearns - could see the market seize up. Banks have asked to keep total reserves of $£ 23.54 \mathrm{bn}$ on deposit that they can borrow to meet short-term financing needs if they cannot borrow in the interbank market. This is up from the nearly $£ 20$ bn they had on deposit until yesterday. This is money the banks keep on deposit at the Bank, earning interest, but that they can access when the cost of borrowing from other banks becomes too high."

${ }^{6}$ The interaction effect is reversed for banks with more deposits as they have greater uncertainty in payment activity due to depositor withdrawals adding significant uncertainty around special calendar days.
} 
GILT collateral, and unsecured rates and volumes from the British Bankers' Association and Wholesale Markets Brokers' Association. We study the behavior of inter-bank markets in the period January 2007 till June 2008, when this paper was first drafted.

In linking liquidity to rates, there might be an important endogeneity problem at play: While an exogenous shock to aggregate liquidity would be expected to enable inter-bank markets to clear at lower rates, when aggregate liquidity is the endogenous outcome of banks' strategic choices, it may be correlated with the very factors that would cause the rates to rise. For example, bank liquidity may have risen due to an anticipated shortage of aggregate liquidity which would raise the opportunity cost to each bank of giving up liquidity to other banks. A shortage of bank-level capital would have a similar effect on liquidity and rates. Bank liquidity may also be responsive to expected rise in future inter-bank rates, for example, if distribution of liquidity was expected to be highly concentrated with some players. And, banks may be hoarding liquidity precisely due to high rates in inter-bank markets that in turn might be reflecting counterparty risk concerns. Thus, identifying and quantifying the causal effect of liquidity on rates calls for isolation of a component of liquidity that is exogenous to contemporaneous rates.

To this end, we exploit an idea based on Furfine (2000) that the payment and settlement activity per se is not expected to affect inter-bank rates, other than through its effect on bank liquidity. Crucially, since the payment and settlement activity is driven by calendar day effects, we show that it tends to be essentially uncorrelated over time. Thus, a lagged measure of such activity is potentially an instrument for bank liquidity while studying its effect on rates. Formally, inter-bank rates on a given day depend on the liquidity reserves of banks on that day, which we assume includes a component of reserves adjusted to yesterday's payment and settlement activity (the instrument) and a component adjusted in anticipation of today's uncertainties (the endogenous component). We conduct a three-stage least squares estimation linking liquidity to rates and verify econometrically the validity of our instrument.

The results reveal a strong causal effect of liquidity on inter-bank rates, but in a manner that differs sharply between pre-crisis and post-crisis periods. When evaluated at the breakpoints of aggregate liquidity (August 9, 2007 and March 13, 2008), the effect of (instrumented) liquidity is to raise overnight inter-bank rates in the period during the crisis. In contrast, this relationship is significantly negative in the period prior to the crisis. We do not find any significant effect on volume, but what is striking is that the effect on secured rates is as high and significant as the unsecured rates. Indeed, even the simple time-series plots of the overnight secured and unsecured rates relative to BoE policy rate track each other rather well (see Figure 2). We do not find much of an effect of daily aggregate liquidity on the 3-month rates and volumes (we only have data on unsecured 3-month volume), however when we employ a 20-day lagged moving average of aggregate liquidity, the effect on rates is again large and weakly significant.

We interpret these findings - especially the fact that effects on rates are similar for secured and unsecured inter-bank lending - to imply that these markets experienced stress during the crisis not per se due to counterparty risk concerns. Instead, the findings suggest that the stress was most likely due to each bank engaging in liquidity hoarding due to a precautionary response to its own heightened funding risk in markets for external finance (for example, wholesale markets) in wake of increased risk or anticipation of losses and capital shortfalls. The contrast between the pre-crisis and post-crisis periods lends further credibility to this conclusion.

This interpretation is potentially important also to understanding the apparently puzzling 
"stigma" associated with the use of central bank emergency lending facilities. The standard assumption in money markets is that if the inter-bank rate is higher than the (say, the BoE) policy rate, then banks release their surplus liquidity, if any, for "arbitrage" which involves lending at the higher rate and borrowing at the policy rate. This activity should have the effect of bringing the lending rate down to the policy rate. In normal times, there is no reason for banks to be concerned that markets and investors might confuse the access of central bank's emergency lending facilities with solvency concerns of the arbitraging bank. Hence, this arbitrage works well and the effect of aggregate bank liquidity shocks is to lower inter-bank rates. However, in an environment where markets and investors are concerned about some risk of insolvency at large, settlement banks but do not yet know which banks are likely to fail, the stigma in accessing central bank emergency lending for arbitrage purposes is natural. Hence, in spite of a central bank willing to borrow or lend in sufficient quantities at the policy rate, banks effectively behave like financially constrained firms and charge more for transferring liquidity onto others. Ex post, the solvency fears have turned out to be realistic and one could argue that the stigma might in fact be a reflection of underlying insolvency problems.

Finally, we conduct two tests that show that the variability of inter-bank rates induced by precautionary liquidity hoardings can have substantial economic effects. In one test, we ask the question if the effect on the aggregate inter-bank rates is uniform for all borrowing banks or limited to the crisis-affected ones. As mentioned above, banks that made greater losses in the sub-prime crisis held higher precautionary liquidity reserves. It could be that the inter-bank rates rose only for these banks and not for the other settlement banks. We find that this is not the case. When we exploit the bank-level variation in the inter-bank unsecured borrowing rates and allow it to be determined by bank's own liquidity as well as that of other banks, we find that it is other banks' liquidity that causes the rates to move. And importantly, the group of banks with low losses during the crisis are as exposed to rate rises (in response to other banks' liquidity) as the group with high losses.7 This suggests a contagion-style systemic risk effect could operate through inter-bank markets.

In another test, we show that the monthly household and corporate lending rates (fixed and floating) as well as volumes respond to the variability in inter-bank rates. Overall, as inter-bank rate rises, the lending rates to households and corporates rise and volumes shrink, showing a transmission effect of money-market liquidity to the real economy. Again, at the individual bank level, this transmission effect is stronger for banks that made higher losses during the crisis, and the effect exists mostly during the crisis but not before.

Overall, this evidence suggests that central bank and regulatory attempts to thaw the money market stress and reduce variability of inter-bank rates, if successful, can also have salubrious effects on other parts of banking and real sectors. Our results, however, also suggest that to the extent a part of the stress may emanate from liquidity hoardings of banks with troubled funding and balance-sheet conditions, such thawing should involve addressing the insolvency issue (for example, early supervision and stress tests, and recapitalization of troubled banks) rather than just the lender-of-last-resort liquidity provisions.

The remainder of the paper proceeds as follows. Section 2 provides the relevant institutional details of the UK payment system and money markets. Section 3 documents the regime switch

\footnotetext{
${ }^{7}$ Statistically, the effect is stronger for the group of banks with higher losses during the crisis, but the economic magnitude is of the same order for both groups.
} 
in liquidity reserves of banks and Section 4 shows that liquidity hoardings of banks have a precautionary aspect to them. Section 5 establishes the causal effect of liquidity hoardings on inter-bank rates. Section 6 examines the effect of precautionary hoardings of a set of banks and on other banks' borrowing rates, and Section 7 studies the transmission of inter-bank rates on to household and corporate lending. Section 8 relates our paper to literature and Section 9 concludes.

\section{Institutional Background}

This section provides some important background information. Section 2.1 describes the structure of the payment system and money markets in the UK. Section 2.2 provides an overview of the Bank of England (BoE) monetary policy framework, focusing on the institutional and operational boundaries within which banks are able to manage the liquidity requirements arising from their daily payment activity. Section 2.3 summarizes the range of adjustments to the framework the BoE undertook since August 2007 to restore orderly conditions in money markets.

\subsection{Tiered Structure of the UK Payment System and Money Markets 8}

There are about 400 active banks in the UK. The UK large-value payment system has a "tiered" structure. Tiering means that many (usually smaller) second-tier banks do not settle at the central bank but do so on the accounts of few (larger) first-tier banks also referred to as the settlement banks or clearers. 15 banks are direct participants in the large-value payment system called CHAPS (excluding the Bank of England). Two of the direct participants are foreign owned banks with a narrow retail activity in the UK.

Money markets or inter-bank markets allow participants to manage short-term liquidity positions. The tiered structure described above for the payment system is also reflected in money-market activities. The key players in the Sterling market across all instruments and maturities are the UK clearing banks, other large UK banks, and large US and European banks. The provision of liquidity through the system operates via a 'top-down' structure. Along the top tier, the big four 'clearers' provide funding horizontally to each other and vertically to other counterparties (typically building societies and European banks with whom they have an established relationship). Smaller players are not inclined to provide liquidity horizontally to competitors and instead are more likely to pass it vertically up the system. So below the top tier, horizontal movement is very limited.

\subsection{Liquidity Management Under the Current Monetary Policy Framework}

An alternative to banks for obtaining short-term liquidity is to rely on reserves balances held at the central bank. In the UK, a combination of reserves accounts, reserves averaging and the standing facility corridor is used to limit volatility in overnight interest rates over each maintenance period. Under the current monetary policy framework implemented in May 2006, 37 UK banks and building societies that are members of the scheme set their "target" balances

\footnotetext{
${ }^{8}$ This section relies on information collected from market participants.

${ }^{9}$ This section relies heavily on "The framework for the Bank of England's operations in the sterling money markets (The 'Red Book')" available at http://www.bankofengland.co.uk/publications/news/2006/054.htm and Clews (2005).
} 
(reserves) at the beginning of each maintenance period (Monetary Policy Committee's decision date until the next) and undertake to hold balances, remunerated at the official Bank rate (or the policy rate), that on average meet the pre-set target over the maintenance period. Participation in the reserves-averaging scheme is voluntary other than for the fist-tier, or in other words, settlement banks, which join the scheme automatically because their role in the payments system entails them having reserves accounts, and so maintaining balances, with the central bank. Prior to the crisis, if a member's average balance was within a $+/-1 \%$ range around the target (averaging reserves balances at the end of each calendar day over the maintenance period as a whole), the balance would be remunerated at the official Bank rate.

Subject to meeting the monthly target balance and avoiding overnight overdrafts, reserves balances can be varied freely to meet day-to-day liquidity needs. For example, funds can be moved on and off reserves accounts up to the close of the payments system in order to accommodate unexpected end-of-day payment inflows and outflows. In this way, reserves balances can be used by banks as a liquidity buffer.

Within the ceilings set on reserves targets, reserves banks can also change their reserves target from month to month in response to, for example, variations in the size or uncertainty of their payments flows. Settlement banks can also draw on reserves balances during the day to bridge any gap between payments made and expected receipts. For this purpose, holding reserves is an alternative to borrowing from the central bank during the day against eligible collateral. The routine provision of intra-day liquidity to settlement banks against eligible collateral together with reserves balances, provides the necessary lubricant for the working of the Sterling payments system, ensuring that settlement banks are able to make payments in advance of expected receipts later in the day. Intra-day lending from the $\mathrm{BoE}$ to the settlement banks is interestfree, but it entails a large penalty if not reimbursed by the end of the day.

Individual institutions also need to have plans to manage liquidity in times of stress. Smaller banks can obtain liquidity insurance from larger banks by paying for committed lines of credit. But larger banks generally cannot buy insurance from each other without imposing an unacceptable level of (contingent) counterparty credit risk. Thus, they have to self-insure, which they do in Sterling by holding either balances on their reserves account at the Bank or high-quality assets that can be exchanged for central bank money in the open market operations (OMOs) or through the Bank's standing (or semantically, emergency) lending facility.

OMOs are used to provide to the banking system the amount of central bank money needed to enable reserves banks, in aggregate, to achieve their reserves targets. OMOs comprise shortterm repos at the official Bank rate, long-term repos at market rates determined in variable-rate tenders, and outright purchases of high-quality bonds The Bank of England (BoE) accepts as counterparties in its open market operations (OMOs): (1) banks and building societies eligible to participate in the reserves scheme; and (2) other banks, building societies and securities dealers authorized under the Financial Services and Markets Act 2000 that are active intermediaries in the sterling markets. Standing deposit and (collateralized) lending facilities are also available to eligible UK banks and building societies and may be used on demand. In normal circumstances they carry a penalty, relative to the official Bank rate, of $+/-25$ basis points on the final day of the monthly reserves maintenance period, and of $+/-100$ basis points on all other days.

An important event in Sterling money markets prior to the onset of the crisis in August 2007 was the so-called "uncovered" OMO. In an OMO to supply reserves, counterparties bid 
for a quantity at a fixed BoE Rate. This fixed-rate bidding has one potential undesirable consequence that given the amount of reserves each counterparty actually desires, the size of their bid is determined by their expectation (or guess) as to how much other counterparties will bid for. That can set up a dynamic where, from week to week, the extent to which a short-term repo OMO is covered is on a rising or falling trend. If, for example, a counterparty thinks its peers will bid for much more than they in fact desire, then it too must do the same in order to be allotted roughly what it actually wants. If the cover ratio is on a declining dynamic, that can potentially lead eventually to an "uncovered" OMO, as happened in June 2007, before the turmoil, which means that reserves are undersupplied and interbank rates go up dramatically due to lack of reserves relative to banks' targets.

The Money Market Liaison Group at Bank of England thought that the reaction to the uncovered OMO in end of June 2007 may have reflected some money market participants not fully appreciating how the Bank's sterling monetary framework was supposed to work. But it provided a useful case study and a repeat was thought unlikely. From the standpoint of our analysis, the uncovered OMO raises the issue that any differential effect we observe pre- and during the crisis might be due to the July 2007 episode. We address this throughout the paper by always controlling through a dummy variable for the uncovered OMO episode.

\subsection{Adjustments to the Monetary Policy Framework during the Sub-Prime Turmoil}

The current monetary policy framework of the Bank of England is also designed to enable it to continue achieving its primary rate-setting objective while responding to any sudden or pronounced shifts in demand for central bank money. Such changes might occur in the face of major operational or financial disruptions to the Sterling money markets or their supporting infrastructure. In such circumstances, demand for central bank money might rise if the money markets were no longer working effectively to distribute reserves around the banking system. Hence, during the current turbulence the $\mathrm{BoE}$ undertook a range of adjustments to its framework giving leeway for banks to build up larger liquidity buffers:

(1) On September 13th and 18th 2007, the BoE offered an extra £4.4bn (each time) in its regular weekly open market operations, amounting to $25 \%$ of the aggregate reserves target for the current maintenance period. This was accommodated by an increase in the reserves band around target from $1 \%$ to $37.5 \%$. These actions were taken to help offset the disturbance to conditions in the short-term money markets following the announcement of lender of last resort assistance to Northern Rock on September 14th 2007.

(2) The BoE further announced on 19th September 2007 that in order to alleviate strains in longer-maturity money markets it would conduct auctions to provide funds at 3 month maturity against a wider range of collateral (including mortgage collateral) than in the BoE's weekly open market operations.

(3) For the maintenance period beginning on October 4th 2007, the ranges around reserves banks' targets within which reserves are remunerated were widened from $+/-1 \%$ to $+/-30 \%$. The target ranges remained at this level until July 10 th 2008 when they were reduced to $+/-20 \%$. Further, in view of the increase in the reserves targets set by reserves scheme members and the potential for future increase, with effect from the maintenance period starting on May 8th 2008, the BoE more than doubled the reserves target ceiling it sets for each reserves scheme member. 
(4) On April 21st 2008, the BoE introduced the special liquidity scheme to deal with the overhang of existing assets on banks' balance sheets. The scheme allows banks and building societies to swap for up to three years some of their illiquid assets for liquid Treasury Bills. In other words, the purpose of the Scheme is to finance part of the overhang of currently illiquid assets by exchanging them temporarily with more easily tradable assets. The banks can then use these assets to finance themselves more normally. All of the banks and building societies that are eligible to sign up for the standing deposit and lending facilities within the Bank's Sterling Monetary Framework are able to take part in the Scheme.

With this background description, we move to the analysis of bank liquidity.

\section{Regime Shifts in Bank Liquidity}

In this section we use an event study approach to investigate first-tier (settlement) banks' liquidity holdings during the crisis.

\subsection{Descriptive Statistics}

We measure the aggregate overnight liquidity as the sum of the reserves accounts held by the ten UK first-tier banks at the central bank and measured at 5 am each day. The total liquidity is the sum of their overnight liquidity and their intra-day liquidity. The intra-day liquidity is the aggregate maximum collateral settlement banks post during a day to obtain intra-day credit from the central bank, including the collateral held overnight in fulfillment of regulatory liquidity requirement. The data are obtained from the Bank of England. All data are daily and most of our tests cover the period 02 January 2007 to 30 June 2008.

Table 1 reports various descriptive statistics (mean, standard deviation, minimum, maximum, quantiles) of the overnight and total liquidity held by first-tier banks. This is reported for three periods: whole sample period (Panel 1a), pre-August 9th 2007 (Panel 1b) and postAugust 9th 2007 (Panel 1c). Panel 1d reports a test of the difference in means between the two sub-periods. The overnight liquidity is 27 per cent higher post August 9th and the total liquidity 24 per cent higher. These differences are significant statistically at the $1 \%$ level. For both variables however, we notice that the standard deviation is similar across the two periods. This suggests that the variations in the means resulted from abrupt permanent rises in the level of both series.

\subsection{Event Study}

To understand these shifts in banks liquidity further, we identify the exact periods when banks revised their liquidity demand and relate these to relevant market news obtained from Bloomberg's real-time news service. We employ the Bai and Perron (1998) test which estimates the timing of permanent level shifts in a time series. This method applies a sequential algorithm that searches all possible sets of breaks and determines for each number of breaks the set that produces the maximum goodness-of-fit. Statistical tests then determine whether the improved fit produced by allowing an additional break is sufficiently large given what would be expected by chance (due to noise). We apply the test to the total and the overnight liquidity. 


\subsubsection{Total Liquidity}

Table 2 a reports the test results for total liquidity. The first column reports the break dates. The second column gives the $95 \%$ confidence interval for each break point. The third column provides the estimated mean of the $(\log )$ liquidity series considered for each window. The fourth column details headlines on dates over the period 1 May 2007 to 30 June 2008 falling within the $95 \%$ confidence interval for any break point shown in bold.

The total liquidity (in logarithm) and estimated breaks are also plotted in Figure 1. The test identifies two upward breaks in the total liquidity. A first $7.2 \%$ increase in the total liquidity occurred on March 3th 2007 and a further 20\% increase on August 8th 2007. The first break is modest in comparison to the second and does not coincide with any key market event. In contrast, August 9th 2007 is widely believed to be the date of money market "freeze" in the UK, European and US money markets, and coincides with the first negative news announcement by a major European bank in Bloomberg headlines. For two weeks in August BNP Paribas suspended redemptions from three money market funds because they did not feel they could fairly value their positions. Before BNP's announcement, loss announcements and other negative news in the headlines were concentrated in the United States, primarily Bear Stearns' hedge funds and also some monoline insurers. A cascade of loss announcements, primarily unscheduled, from US and European banks followed immediately after BNP's announcement as many banks were forced to honor the liquidity and credit enhancements they had sold to asset-backed special purpose vehicles or in some cases take these assets back on balance sheets.

This is preliminary evidence that the most significant break point in total liquidity series potentially reflects a response to the additional funding needs due to recourse of assets back to bank balance-sheets and heightened funding risk as banks could no longer raise overnight financing from short-term asset-backed commercial paper as they were used to. Instead, banks would now have to tap into other forms of borrowing such as through inter-bank markets or repo markets or do external capital-raising which is costly both in terms of adverse selection costs (Myers and Majluf, 1984) and dilution costs arising from debt overhang (Myers, 1977).

\subsubsection{Overnight Liquidity}

Table $2 \mathrm{~b}$ reports results for the overnight liquidity. The test identifies two breaks in the overnight liquidity. The first break, a $24 \%$ increase in overnight liquidity, occurred around September 11th 2007. This is one month later than the major break in the total liquidity. This break is delayed because banks are allowed to revise their reserves targets only from one Monetary Policy Committee meeting to the next. Figure 3 shows that the first increase in the aggregate reserves target occurred on September 6th 2007, the date the first MPC meeting took place after the sub-prime crisis took hold. One can observe in Table $2 \mathrm{~b}$ further increases in the overnight liquidity from mid-September onwards following the BoE decisions to inject extra liquidity in its regular weekly open market operations. For the October maintenance period, banks chose a higher target - around $20 \%$ higher than the aggregate target for the August maintenance period.

At the second break, March 13th 2008, first-tier banks increased their overnight liquidity by an additional 15.5\%. The second break coincides exactly with the collapse of Bear Stearns in the US. Bear Stearns episode reflected yet another freeze, this time in the market for borrowing secured against highly rated asset-backed securities. Traditionally, banks had always assumed they would be able to access this market - the so-called overnight repo market - for short-term 
liquidity needs. The Bear Stearns collapse revealed however that banks could no longer assume in their liquidity stress tests that the worst case scenario was simply the drying up of unsecured funding, but that secured funding may dry up too. This further intensified the funding needs and risks faced by banks and the liquidity response of banks is thus again consistent with a precautionary motive 10

While the higher reserves targets may have reflected anticipation of heightened funding needs and risks, one needs to consider also the fact that banks had access to BoE's standing facilities as an alternative. Hence, the preference for reserves as a way of building liquidity also reflects a reduced tolerance for the risk of using BoE's standing facilities, most likely due to the potential "stigma" of accessing them during period of market stress. Specifically, the marginal benefit of an additional unit of reserves is the insurance it provides against having to use the standing facilities (SF) following an unexpected payment shock in late trading. The expected cost of using the SF is a function of the direct penalty in using it (which remained constant or in fact was lowered by the BoE during the crisis), the indirect penalty due to stigma, and the size of unexpected payment shocks. This cost must be traded off against the opportunity cost of not deploying elsewhere an additional unit of reserves, which is typically the spread between policy rate and the overnight (secured) market rate. Within a maintenance period, settlement banks can increase their liquidity buffer either by reducing lending to households and firms or by reducing net lending to second-tier banks. Across maintenance periods, i.e., from one MPC meeting to another, reserves targets can themselves be varied.

\section{Evidence of the Precautionary Motive}

In order to tease this tradeoff faced by banks in building up reserves, we examine the explanatory power of payment shock uncertainty for aggregate liquidity and of bank-level funding risks for bank-level liquidity.

\subsection{Aggregate Evidence}

Our first test of the precautionary motive consists of estimating changes in aggregate liquidity in response to changes in aggregate payment activity. The underlying idea is that on days of high aggregate payment activity, some individual banks might end up with significant payment needs but the distribution - that is which individual banks will face these needs - is uncertain. The data for payment activity are from the Bank of England payment database. The daily payment activity is measured as the sum of all transactions that flow through the large-value payment system (CHAPS), net of interbank loans activity, value measuring the Sterling amount and volume measuring the number of transactions. A higher payment value controlling for number of transactions implies greater payment risk; conversely, higher payment volume controlling for payment value implies small size transactions and lower payment risk.

\footnotetext{
${ }^{10}$ Note that the liquidity demand of banks in this case reacted more or less immediately due to the BoE decision on October 4th 2007 to widen the band around target within which reserves are remunerated from $+/-1 \%$ to $+/-$ $30 \%$. If there is an upward shock to aggregate reserves demand within a maintenance period, the Bank can widen the range to allow it supply additional reserves without penalizing banks or needing to drain reserves later in the maintenance period. In March 2008, the wider (+/-30\%) range allowed the Bank to supply the additional reserves to the banking sector without further changes to the range.
} 
Table 1 shows the summary statistics for payment value and volume pre-crisis and during the crisis. Strikingly, there is virtually no difference in the economic magnitude of payment activity by itself over the two periods. This is important for our identification to follow as any differential response of bank liquidity to this activity must thus arise from the perceived cost of managing payment shocks through means other than liquidity reserves. Figures 4 and 5 plot the payment activity in value and volume (in logarithm), respectively. At first sight, these series appear to be white noise processes. A Portmanteau test confirms this observation. For both series the lag-one autoregressive coefficients are small (not reported). The Portmanteau test for lag-one has p-value of 0.29 for the aggregate payment value and 0.12 for the aggregate payment volume rejecting the null hypothesis that the first lag autocorrelation is different from zero.

Importantly though, payment risk measured as changes in aggregate payment activity is in fact predictable by banks due to calendar effects. In fact, APACS, the UK payments association, claim to be able to forecast close to 100 per cent of the fluctuations in payment flows. Table 3 reports the effects of a non-exhaustive set of calendar dummies on payment activity, which includes holidays in United States and the United Kingdom, and fixed effects for day of the week, quarter, and beginning and end of each month. With these few dummies we are able to predict 75 per cent of the variation in the payment volume and 40 per cent of the variation in payment value. Important calendar effects are (i) United States holidays which are associated with a 58 per cent drop in the value of payments activity, (ii) Days around the United Kingdom holidays when there are, for instance, higher than usual deposit withdrawals; and (iii) fourth quarter effect which is negative also.

To investigate how banks adjusted their liquidity reserves in aggregate at the start of the day in response to payment activity measured at the end of the day (which we have shown to be predictable due to calendar effects), and whether this adjustment differed before and during the crisis, we estimate the following specification:

$$
\left\{\begin{array}{l}
\text { OLiq } q_{t}=\alpha_{o} \cdot P_{t}+\sum_{s=2}^{3} \beta_{o}^{s} \cdot P_{t} * \text { break }_{t}^{s}+\sum_{s=1}^{3} \gamma_{o}^{s} \cdot \text { break }_{t}^{s}+\delta_{o} \cdot Z_{t}+\varepsilon_{t}^{o}, \\
\text { TLiq } \\
=\alpha_{l} \cdot P_{t}+\beta_{l} \cdot P_{t} * \text { break }_{t}^{1}+\gamma_{l} \cdot \text { break }_{t}^{1}+\delta_{l} \cdot Z_{t}+\varepsilon_{t}^{l},
\end{array}\right.
$$

where $O L_{i q}$ is the aggregate overnight liquidity on day $t, T L i q_{t}$ is the total liquidity, $P$ is a vector of measures of aggregate payment activity (the volume and the value), and all quantities (payment activity and liquidity) are in logarithm. The breaks are based on estimations in Table 2: break $_{t}^{1}$ is a post August 8th 2007 dummy; break $k_{t}^{2}$ is a post September 11th 2007 dummy; break $k_{t}^{3}$ is a post March 13th 2008 dummy. $Z_{t}$ is a vector of control variables including a dummy for days in the last week of June 2007 when the uncovered OMO occurred (see Section 2.2 explaining why we need to control for this failed OMO that affected interbank markets prior to onset of the crisis); a dummy that takes value one on days when the regular weekly open market operations take place (every Thursday); maintenance days' fixed effects; and dummies marking two periods when alternative adjustments to the monetary policy framework were in place: the widening of bands around target between October 5th 2007 and May 1st 2008; and the higher ceiling set on reserves targets from May 2nd 2008 onwards. Including these dummies helps control for shifts that one-time adjustments to the monetary policy framework might have caused on the aggregate liquidity.

The system is estimated using seemingly-unrelated-least-squares (SURE). The estimates are reported in Table 4. The results in columns (1) through (6) show that the settlement banks 
react to an (expected) increase in payment value on day $t$ by holding more liquidity in aggregate at the start of the day. Controlling for the aggregate payment value a decline in the aggregate payment volume, i.e. an increase in the average payment size, also causes settlement banks to hold larger buffers at the start of the day. Interestingly in columns (3) and (5), for the overnight liquidity, the effect is significant statistically only during the crisis, that is, following September 11th $2007\left(b r e a k_{t}^{2}\right)$, the first MPC date after the onset of the crisis. In other words, aggregate bank liquidity rose more on days with high payment activity in terms of value, during the crisis but not before, consistent with a precautionary response to an increase in funding risk faced by banks in managing the risk of payment shortfalls. In terms of magnitude, in column (3) a one per cent increase in aggregate payment value is associated with a 0.27 percent increase in the overnight liquidity during the crisis 11

\subsection{Bank-level Evidence}

Our second test of the precautionary motive exploits daily bank-level data. We relate the individual liquidity buffers of banks to the payment risk on the same day and to individual bank characteristics using the specification:

$$
\left\{\begin{array}{l}
\text { OLiq } i t=\alpha_{o} \cdot P_{t}+\sum_{s=2}^{3} \beta_{o}^{s} \cdot P_{t} * \text { break }_{t}^{s}+\sum_{s=2}^{3} \gamma_{o}^{s} \cdot X_{i(t)} * \text { break }_{t}^{s}+\sum_{s=1}^{3} \delta_{o}^{s} \cdot \text { break }_{t}^{s}+\theta_{o} \cdot Z_{t}+\omega_{i}^{o}+\varepsilon_{t}^{o}, \\
\text { TLiq }
\end{array}\right.
$$

where in new notation, $i$ stands for a bank subscript, $\omega_{i}$ is a bank fixed effect, and $X_{i}$ is a vector of three variables measuring banks' realized health during the crisis and its funding risk due to maturity mismatch measured at the inception of the crisis: (1) losses disclosed (which include write-offs) in the period from June 2007 to March 2008 as a ratio of total assets; (2) the ratio of retail to interbank deposits in June 2007 (i.e. pre-crisis); and (3) the equity price fall relative to mean 2006 valuation and normalized by 2006 standard deviation. Losses disclosed are an imperfect measure of realized solvency issues since some banks were prompter at reporting losses than other banks. The ratio of retail to wholesale deposits accounts for the fact that while some banks were not directly threatened by the meltdown of the ABCP market, they were rendered fragile by the dry up of wholesale financing markets due to their relatively small deposit base ${ }^{12}$ Finally, equity price fall should incorporate all public information available on the financial condition of a bank, including anticipation of losses and not just realized losses.

All other variables are as in system (1), except that because of large differences in size between banks, rather than taking logarithms directly, the overnight liquidity for a bank is normalized by subtracting the bank's mean and dividing by the bank's standard deviation of liquidity calculated over the first twelve months of the sample. In this way, we focus on abnormal

\footnotetext{
${ }^{11}$ In columns (5) and (6), it is noteworthy that the flexibility introduced by the widening of the bands around reserves target and the higher ceiling set on reserves target led settlement banks to reduce their overnight liquidity buffers by about 13 per cent and 9 per cent, respectively, relative to the period August-September 2007.

${ }^{12}$ A classic example of this is the run on Northern Rock in September 2007. Shin (2009) provides descriptive statistics showing that Northern Rock's reliance on securitization was not an immediate factor in its failure since its securitization vehicles issued long-term notes to investors, but that its problem stemmed from its high leverage coupled with reliance on institutional investors for short-term funding. An analysis of the structure of its balance sheet pre- and post-run shows that the first and most damaging run on the bank took place in its short- and medium-term wholesale liabilities.
} 
variations in each bank's liquidity. Table 5 reports descriptive statistics of the main variables used in the estimation. There is significant variability across banks in the measures of bank health and funding risk. For all banks, retail deposits are larger than interbank deposits but the ratio varies between 1.4 and 17. More than 50 per cent of the banks in our sample did not report any losses as of March 2008, but all did between then and end of our sample period. Equity prices experienced dramatic swings over the sample period for many banks.

Table 6 a reports the SURE estimates of the specification for bank-level overnight liquidity ${ }^{13}$, The precautionary liquidity response to variations in payment activity is confirmed. As in Table 4, on average banks increase their overnight liquidity buffers in response to larger transactions (lower volume for same total value of payments). In contrast to Table 4 however, bank-level estimates show a liquidity response to larger payment value only following March 13th 2008 $\left(\right.$ break $\left._{t}^{3}\right)$.

Column (2) shows that banks which reported larger losses during the crisis increased liquidity reserves more immediately after September 11th $2007\left(\right.$ break $\left._{t}^{2}\right)$; whereas Column (3) shows a similar effect for banks relying less on retail deposits relative to interbank deposits. Columns (4) and (5) examine the interaction of these two effects and show that banks which are more vulnerable to an interbank market freeze (low retail to interbank deposits ratio) hoarded more liquidity if they subsequently also reported larger losses, and vice-versa. Also column (6) shows that banks which lost more stock market value following September 11th 2007 (relative to 2006 valuations) built larger liquidity buffers during the crisis. These effects are all significant at conventional levels and large in terms of economic magnitude. For instance, banks which disclosed a loss ratio one standard deviation above the mean increased their overnight liquidity by an additional 25 per cent of a standard deviation.

In Table $6 \mathrm{~b}$ we allow for heterogeneity in the precautionary reaction of banks, based on their three characteristics, to payment risk. In column (1) we allow the coefficients on payment value and payment volume to vary for banks which disclosed higher than median losses and banks which disclosed lower than median losses. The precautionary reaction to payment risk is about 50 per cent larger for banks which reported higher than median losses. Column (2) shows that the precautionary reaction to payment risk is higher for those banks that relied less on wholesale funding. At first sight this is counter-intuitive but it is explained by the fact that payment shocks are more likely for the large retail banks ${ }^{14}$. In column (3) the precautionary reaction to payment risk is larger for those banks whose equity price declined more during the crisis. The liquidity demand of low risk banks also reacts more to fluctuations in the aggregate payments activity, but only post-March 2008, but their reaction in addition to being less immediate, is about one-third smaller in magnitude.

To sum up, the findings in the section confirm our hypothesis that the increase in the aggregate liquidity witnessed during the crisis has been (at least partly) precautionary. During the crisis banks hoarded liquidity against predictable payment shocks, but not so pre-crisis. Further, this precautionary reaction was unequal across banks being more pronounced at weaker

\footnotetext{
${ }^{13}$ In interest of space, we do not report the estimates for total liquidity which are qualitatively similar. These estimates are available upon request.

${ }^{14}$ We checked this by regressing each group's fraction of the aggregate payment activity on the same calendar effects similar to those used in Table 4. The results revealed that the calendar effects explain a larger fraction of the payment activity of the retail banks than the non-retail banks, likely due to deposit withdrawal shocks around holidays. These results are available upon request.
} 
banks and banks with greater funding risk.

\section{$5 \quad$ Effect of Liquidity Hoarding on Money Markets}

In the second half of the paper, starting with this section, we explore what were the consequences of the increase in hoarding of liquidity by first-tier banks for inter-bank markets, and subsequently the real economy. We investigate these issues in turn, investigating in this section how movements in liquidity demand by banks altered inter-bank rates and volumes before and during the crisis.

\subsection{Revised Arbitrage Condition in Stressed Conditions}

Theoretically, banks set reserves targets to equal the marginal cost and the marginal benefit of holding one additional unit of reserves. In normal times, the cost of using the standing lending facility to meet liquidity needs is low due to the absence of stigma. Then, reserves averaging over a maintenance period ensures by "arbitrage" that market interest rates do not diverge materially from the policy rate. The arbitrage works as follows. For instance, if overnight market interest rates are higher on a particular day than the policy rate, a bank can run down its reserves balance in order to lend in the market, expecting to be able to borrow more cheaply in the market in order to hold higher reserves balances on subsequent days. By contrast, if market rates are lower, a bank can borrow in the market in order to build up its reserves balance. Typically, the effectiveness of this arbitrage mechanism is affected by the width of the range of reserves allowed by the monetary policy implementation and by the willingness of banks to take reserves close to the edge of their ranges given that unexpected late payment flows could leave them needing to use a standing facility at the end of the day.

In stressed conditions, however, the stigmatization of the standing facility is high and this can curb active liquidity management by banks. The incentive is for banks to hold larger buffers over the maintenance period to reduce the risk of having to use the standing lending facility to meet unexpected late payment shocks. The private benefit of holding one additional unit of reserves is high and hence banks charge a high liquidity premium to release their reserves. In other words, in stressed conditions banks release their excess precautionary liquidity only if the return on liquidity exceeds the high private benefit, causing interbank rates to be higher.

In our empirical work, we aim to identify both these effects: first, on liquidity hoarding of banks between normal and stressed times, and second, of liquidity hoardings on interbank rates, in particular, on the deviation between interbank rates and Bank of England policy rates.

\subsection{Measuring the Liquidity Effect: An Instrumental Variables Approach}

A correct identification of the causal effect of variations in liquidity demand on money market rates ought to correct for reverse causality and omitted variables bias. Overnight rates may deviate from the policy rate due to a number of factors other than variations in the aggregate level of overnight liquidity. For example, the secured overnight rate can deviate from the policy rate because the central bank accepts a wider range of collateral than just gilts and allows collateral substitution through the life of the transaction. And unsecured rates embody a premium for counterparty risk so can deviate from target because of credit, rather than liquidity, factors. 
To address these issues, we once again exploit variations in payment and settlement activity. Section 2.2 highlighted mechanisms whereby payment activity correlates with the settlement banks' overnight liquidity buffer and Section 4.1 provided supporting evidence. We take advantage of this relationship in teasing out the effect of bank liquidity on money market rates.

Formally, we specify liquidity on day $t$ (measured at the start of the day) $l_{t}$ as an autoregressive process of order one:

$$
l_{t}=\alpha l_{t-1}+\beta P_{t}+\varepsilon_{t}^{l},
$$

where the precautionary demand for liquidity is captured by the dependence of $l_{t}$ on $P_{t}$, the payment activity on day $t$ (assuming banks are able to make a reasonable forecast of their payment activity). We assume based on evidence presented in Section 4.1 (see Figures 4 and 5) that $P_{t}$ is a white noise process:

$$
P_{t}=\varepsilon_{t}^{P}
$$

Then, equation (3) can be rewritten as:

$$
l_{t}=\alpha^{2} l_{t-2}+\alpha \beta P_{t-1}+\beta P_{t}+\varepsilon_{t}^{l}
$$

In other words, (within a maintenance period) liquidity at time $t$ is a function of all the past history of payment activity. Next, we write the interbank market rate $r_{t}$ as a linear function of both $l_{t}$ and $P_{t}$ :

$$
r_{t}=\gamma l_{t}+\delta P_{t}+\varepsilon_{t}^{r}
$$

That the market rate on a given day is a direct function of the payment activity on that day follows from Furfine (2000). His argument goes as follows. Payment flows on any given day are positively correlated with reserves balance uncertainty. As uncertainty generates a precautionary demand for reserves, days with higher payment flows are associated with upward pressure on the market rate. In other words, on busier days, banks desire to hold a larger cushion of reserves to protect against penalties for overnight overdrafts. In equilibrium, this generates a positive relationship between payments volume and the market rate. If this argument holds $P_{t}$ is not a valid instrumental variable for $l_{t}$, in studying the effect of liquidity $l_{t}$ on interbank rate $r_{t}$. However,because $P_{t}$ is a white noise process $P_{t-1}$ is potentially a valid instrument for $l_{t}$.

\subsection{Measuring the Liquidity Effect: Results}

\subsubsection{Money Markets Data}

Interest rates and volume data are from the British Bankers' Association and Wholesale Markets Brokers' Association. The secured rate is the Gilt Collateral (GC) rate both for overnight and 3-month. The unsecured overnight rate is the SONIA ${ }^{15}$ rate for overnight and the Libor for 3 month. The 3-month unsecured volume is from the Bank of England; derived using an algorithm similar to Furfine (1999) adjusted to account for an interest payment larger than that for overnight loans.

Table 7 reports descriptive statistics of the data. The unsecured rate spread to policy rate is unchanged during the crisis. The secured rate spread to policy rate is 2.41 basis points higher during the crisis than pre-crisis but with huge variability both immediately before and during

\footnotetext{
${ }^{15}$ SONIA stands for sterling overnight index average. It tracks actual Sterling overnight funding rates experienced by market participants.
} 
the crisis. Term rates, in particular the 3-month Libor, skyrocketed during the crisis with their spread over the overnight index swap spread having jumped from 10 bps to 70 bps.

An apparently puzzling observation is that the secured (Gilt) rate has increased more than the unsecured rate. Coincidentally, both the secured volume and the unsecured volume have increased post-August 9th 2007, but the increase has been more than twice larger for secured lending (45 per cent against 13 per cent). As we explain below, this might indicate a heightened market segmentation during the crisis, that is, different sets of banks borrowing in the two markets ${ }^{16}$ Note that a deterioration in the quality of collateral pledged cannot be an explanation for why secured rates have increased more from before crisis to during the crisis, compared to unsecured rates, because we focus on the Gilt rate where quality of collateral was close to unquestionable (at least until the Lehman bankruptcy).

Term unsecured (CHAPS) volume has increased by 19 per cent during the crisis, i.e., much less than overnight lending. This, combined with the observation that term spreads skyrocketed, suggests that increases in supply were insufficient to meet increases in demand in term markets more than in overnight markets. In other words, the compensation demanded by UK banks to lend to other banks over periods longer than overnight rose coincidentally with the rise in the aggregate demand for liquidity, and explains why interbank lending became increasingly concentrated at shorter maturities. Figure 2 shows that sharp movements in the overnight secured rate have coincided with negative market news, e.g., loss announcements and bailouts. ${ }^{17}$ Figure 6 shows positive co-movements between the overnight liquidity and the overnight secured rate during the crisis. Figure 7 shows a similar pattern for the 3-month Libor.

\subsubsection{Regression Specification}

We estimate both price and quantity effects in Sterling money markets and link them to variations in aggregate liquidity using three-stage-least squares (3SLS). Three stage least squares is a combination of multivariate seemingly-unrelated regressions (SURE) and two stage least squares. It obtains instrumental variable estimates, also taking into account the covariances across equation disturbances. If the error terms of the different equations are correlated across equations, then joint estimation of the equations is able to exploit this cross equations correlation to obtain more efficient estimates.

The basic specification we estimate is as follows:

$$
\left\{\begin{array}{l}
Y_{t}=\alpha_{y} \cdot O L i q_{t}+\sum_{s=2}^{3} \beta_{y}^{s} \cdot \text { OLiq }_{t} * \text { break }_{t}^{s}+\sum_{s=1}^{3} \gamma_{y}^{s} \cdot \text { break }_{t}^{s}+\delta_{y} \cdot Z_{t}+\varepsilon_{t}^{y}, \\
\text { OLiq } \\
=\alpha_{o} \cdot P_{t-1}+\sum_{s=2}^{3} \beta_{o}^{s} \cdot P_{t-1} * b r e a k_{t}^{s}+\sum_{s=1}^{3} \gamma_{o}^{s} \cdot \text { break }_{t}^{s}+\delta_{o} \cdot Z_{t}+\varepsilon_{t}^{o},
\end{array}\right.
$$

where $Y_{t}$ is a vector of four variables: the secured (GC) rate spread to policy rate (in basis points);

\footnotetext{
${ }^{16}$ The theoretical models explain the use of collateral as a mechanism to reduce equilibrium credit rationing (Stiglitz and Weiss (1981)) and other problems that arise due to asymmetric information between borrowers and lenders. Collateral induces borrowers to sort themselves ex ante (Bester (1985) and Beaudry and Poitevin (1995)) and/or improve their incentives ex post (Gale and Hellwig (1985)), potentially mitigating problems generated by information gaps between borrowers and lenders. The central implication of these theoretical models is that a shrinking of the information gap between borrowers and lenders should lower the incidence of collateral.

${ }^{17}$ An uncovered OMO caused a peak in overnight rates in the last week of June 2007. The underbidding in the $\mathrm{OMO}$ on June 28th 2007 was explained by a shortage of gilts and other eligible collateral available for borrowing in the securities lending market. See the explanation provided in Section 2.2
} 
the SONIA unsecured rate spread to policy rate; the secured lending volume in logarithm and the unsecured lending volume also in logarithm. All other variables are as in system (1).

\subsubsection{Results}

The estimation results are reported in Table 8 for the overnight market. For comparison, SURE estimates are reported in Panel 8a. Panel 8b reports the 3SLS estimates. The conclusions are robust across alternative specifications though 3SLS (or IV) estimates are larger than SURE estimates and we focus primarily on these.

In terms of the instrument itself, for all specifications the over-identification test statistics validate our instrumental variables. The first-stage estimation of the relationship between the previous day payment activity and the current overnight liquidity buffer is reported in the last part of Table 8b. There is a positive relationship between the current overnight liquidity and the previous day value of payment activity. Controlling for the value of payment activity, positive variations in the previous day volume of payment activity are associated with a lower current liquidity buffer held by first tier-banks, confirming that days of high retail payment activity like Easter and Christmas cash withdrawal days are followed by a decline in the stock of cash settlement banks hold on their reserves accounts. Controlling for the value of payment activity, positive variations in the previous day volume of payment activity also means smaller payments. A larger payment may entail a larger delay cost for banks if the payment size is correlated positively with the size of the customer account. Hence a bank would want to hold a larger liquidity buffer to avoid the cost of having to delay large value payments.

Consider now the results showing the effect of aggregate liquidity on interbank rates. We focus on our preferred specification column (3). While before the crisis a greater overnight liquidity buffer is associated with a significant decline in overnight spreads, during the crisis the liquidity effect (that is, the coefficient on $O L i q_{t} * b r e a k_{t}^{2}$ ) is zero to marginally positive. This is true both for the secured and unsecured rates. The impact on the secured rate tends to be slightly larger. In terms of magnitude, pre crisis a 10 per cent increase in the overnight liquidity buffer is associated with a 6.6 basis points decline in the secured spread. Post September 11th 2007 a 10 per cent increase in the overnight liquidity buffer is associated with a 1.1 basis points rise in the secured spread. This result confirms our theory whereby in stressed conditions banks release their (precautionary) excess liquidity at a liquidity premium that exceeds the direct cost of using the standing facility and the indirect stigma cost.

Note that in column (3), we do not dummy out the uncovered OMO. Instead, we exploit the uncovered $\mathrm{OMO}$ as an exogenous source of variation in rates pre-crisis. This allows us to estimate the liquidity effect more precisely due to the larger variability in the data created by the uncovered OMO. Conversely, column (4) confirms that pre-crisis both secured and unsecured rates skyrocketed as a result of the liquidity shortage generated by the uncovered OMO.

Interestingly, there is no significant incremental effect post 13 March 2008. The coefficient on $O L i q_{t} * b_{r e a k}^{3}$ is not significant statistically and is negative when the dependent variable is the secured spread. The negative sign might suggest that the relationship between the aggregate liquidity and the secured spread is non-linear, but we would expect in that case a similar nonlinearity to show up when the dependent variable is the unsecured spread. A possible reason there is no incremental effect at the second break might be that apart from the two weeks following the Bear Stearns collapse orderly conditions were restored for the period going from 
end-March to end of our sample period. In particular, as described in Section 2.3, on April 21st 2008, the BoE introduced the special liquidity scheme to deal with the overhang of existing assets on banks' balance sheets, allowing banks and building societies to swap for up to three years some of their illiquid assets for liquid Treasury Bills.

Regressions where the dependent variables are volumes traded (second part of Table 8b) show that the secured volume has increased more than the unsecured volume (the coefficient on break $1_{t}$ is 0.278 for the secured volume and 0.232 for the unsecured volume). Interestingly, quantity effects become most significant as the crisis deepens. Post March 13th 2008 (break3) a 1 percentage point increase in $O L i q_{t}$ is associated with a 3.4 percentage points decline in the overnight secured volume. Possible interpretations are twofold. A first interpretation, consistent with the fact that orderly conditions were restored post March 2008 until end of our sample period, leading to overnight secured borrowing being substituted by term secured borrowing. Unfortunately, we cannot test this hypothesis because term secured volume data are not available. But such a rise in maturity would have been supported by the introduction of the Special Liquidity Scheme on 21 April 2008, which allowed banks to swap illiquid assets against Treasury-Bills to be used as collateral in the market. A second interpretation is that there was credit rationing associated with banks hoarding liquidity in the second phase of the crisis. In Stiglitz and Weiss (1981) the interest rate which a bank is willing to pay acts as a screening device: banks who are willing to pay a high interest rate may on average be worse risk. A bank would not lend to another bank who is screened high risk. Bear Stearns' collapse for instance was triggered by its inability to borrow secured against highly rated asset-backed securities.

The effect on the unsecured volume is not statistically significant. This might be explained by the fact that the unsecured market is more segmented than the secured market. Indeed while the secured market is open to a large pool of financial institutions (including investment banks, and other non-commercial banks) the unsecured market is concentrated amongst the settlement banks who access it to manage liquidity shocks arising from their daily payments activity.

In Table 9 we report estimates of the liquidity effect on 3 months secured and unsecured spreads (volumes are not available). In columns (1) to (3), there is no evidence that term markets are dependent on day-to-day variations in the aggregate liquidity. In columns (4) to (6) we estimate the effect of permanent variations in the aggregate liquidity. To do this, we use the 20 days moving average of the aggregate liquidity. This approach is not perfect, however interestingly now the results show a positive effect of permanent variations in the aggregate liquidity on both secured and unsecured term rates (significant at the 10 per cent level) during the crisis. The liquidity effect on the 3-month Libor is large. A 10 per cent increase in the overnight liquidity causes a 26 basis points jump in the 3-month Libor.

We interpret these findings - especially the fact that effects on rates are similar for secured and unsecured inter-bank lending - to imply that these markets experienced stress during the crisis not per se due to counterparty risk concerns. Instead, the findings suggest that the stress was most likely due to each bank engaging in liquidity hoarding due to a precautionary response to its own heightened funding risk in markets for external finance (for example, wholesale markets) in wake of increased risk or anticipation of losses and capital shortfalls. The contrast between the pre-crisis and post-crisis periods lends further credibility to this conclusion.

Overall, we interpret these findings - especially the fact that effects on rates are similar for secured and unsecured inter-bank lending - to imply that these markets experienced stress 
during the crisis not per se due to counterparty risk concerns. Instead, the findings suggest that the stress was most likely due to each bank engaging in liquidity hoarding due to a precautionary response to its own heightened funding risk in markets for external finance (for example, wholesale markets) in wake of increased risk or anticipation of losses and capital shortfalls. The contrast between the pre-crisis and post-crisis periods lends further credibility to this conclusion.

\section{Contagion Effect}

We showed earlier that the regime shifts in aggregate overnight liquidity can be explained by a precautionary reaction at weaker banks. We also showed that the rise in aggregate liquidity in the crisis raised average interbank rates. This latter effect could be due to a rise in the borrowing cost of weaker banks and/or due to a rise in the lending rates of weaker banks. In this section, we try to separate these effects. Specifically, we investigate whether the idiosyncratic reactions at some banks had the contagious effect of causing interbank rates to rise for all other banks 18 ,

A first form of contagion test we explore is an individual bank's vulnerability to hoarding of liquidity by other banks. A second form of contagion inquiry is instead to look at the effect of one bank's hoarding of liquidity on other banks' borrowing cost.

To assess the first form of contagion we run the following regression:

$$
\text { Spread }_{i t}=\alpha^{s} * O L i q_{i t}+\beta^{s} * O L i q_{i^{-} t}+\theta_{s} \cdot Z_{t}+\omega_{i}^{s}+\varepsilon_{i t}^{s}
$$

where Spread is the (transaction-weighted) unsecured spread to policy rate paid on overnight loans extended to bank $i$ on day $t$ (only unsecured market data are available by bank); OLiq is the overnight liquidity held by bank $i$; and $O L i q_{i^{-} t}$ is the aggregate overnight liquidity held by all banks other than bank $i$. The vector $Z_{t}$ is defined as in system (1). Descriptive statistics of the main variables used in the analysis are in Table 8 . The quantity variables (liquidity and payment activity) are normalized due to large differences in size across banks, as before by considering number of standard deviation changes from the mean, calculated over the first 12 months of the sample period.

To assess the second form of contagion we replace Spread $_{i t}$ by $\operatorname{Spread}_{i^{-} t}$. We estimate each equation by 2SLS using $P_{i t-1}$, and $P_{i^{-} t-1}$ as instruments for $O L i q_{i t}$ and $O L i q_{i^{-}}$, where $P$ is a vector of payment activity measures (volume and value). We have four instrumental variables for two endogenous variables. We report regressions where each $\alpha$ and $\beta$ are conditioned on the two break dummies as in system (1). The instrumental variables are interacted similarly.

The results of estimating equation (8) are reported in Table 10a. The dependent variable is Spread $_{i t}$ in columns (1) and (2) and Spread $_{i^{-} t}$ in columns (3) and (4). The first form of contagion is statistically significant and large in magnitude: A bank's borrowing spread is significantly altered by the aggregate liquidity of other banks, and is independent of the bank's own liquidity buffer. In terms of magnitude a one standard deviation increase in $O L_{i q_{i^{-}}}$is associated with a 15.6 basis points decline in Spreadit $_{i t}$ pre-crisis and a 6 basis points increase in Spread $_{i t}$ during the crisis (column 1). The effect is smaller if we dummy out the week of

\footnotetext{
${ }^{18}$ Such a contagion effect has been mentioned during the recent events. See for instance, Wall Street Journal September 17th 2008: "Banks abruptly stopped lending to each other or charged exorbitantly high rates Tuesday, threatening to spread the troubles of American International Group Inc. and Lehman Brothers Holdings Inc. to a broad range of financial institutions and the global economy."
} 
the uncovered OMO but remains meaningful (column 2). In columns (3) and (4) we explore the second form of contagion, that is, whether an individual bank's hoarding of liquidity affects the average borrowing cost faced by other banks. This form of contagion is not statistically significant in either specification.

We investigate the two forms of contagion further by conditioning $\alpha$ and $\beta$ on: (1) a dummy for whether bank $i$ reported a higher (lower) sub-prime loss to total assets ratio; (2) a dummy for whether bank $i$ is one of the top four participants in the inter-bank market in volume terms.

Table 10b reports the estimates conditioning on the loss dummy. Here the first form of contagion remains significant irrespective of whether the bank is high risk or low risk. Interestingly, during the crisis banks that have had a milder precautionary behavior (i.e., low-risk banks) show greater vulnerability to other banks' hoarding behavior (column 2). There is weak evidence also for the second form of contagion. The relationship between Spread $_{i^{-} t}$ and OLiq $i t$ is not statistically significant in column (3), but marginally significant and positive in column (4). The fact that in column (4) the second form of contagion is larger when bank $i$ is high-risk further confirms our prior that the positive relationship between borrowing cost and aggregate liquidity is being driven by the precautionary behavior of weaker banks.

In Table 10c we report the results conditioning on the size of the bank. In columns (1) and (2) we find that small banks's borrowing cost is significantly dependent on variations in their own liquidity buffer while this is not the case for large banks. This is potentially consistent with a thesis that large banks have a more stable funding base than small banks. We also find that on average small banks are more vulnerable to other banks' hoarding behavior than large banks. Further in column (3) we find that the second form of contagion is dependent on bank size. Indeed we find that a large bank hoarding liquidity significantly affects other banks' average borrowing cost while for small banks this effect is smaller and not significant statistically.

To summarize, our analysis shows significant contagion pre- and during crisis in the form of an individual bank's borrowing cost being determined by other banks' hoarding behavior as well as in the form of an individual bank's hoarding behavior affecting other banks' average borrowing cost. The second form of contagion is significant conditional on the bank being a large and significant player in the inter-bank market. Since the effects are present both pre- and during crisis, the critical determinant of whether there is significant contagion or not is whether there is a significant rise in bank liquidity hoardings. The latter was the case since inception of the crisis.

\section{Spillover Effect to the Real Economy}

Having explored interbank contagion we now assess spillover effects from the money markets to the real sector. To be precise, we investigate how banks adjusted their supply of credit to households and the corporate sector with changing conditions in the interbank market.

We measure the transmission of a (temporary) disturbance in interbank markets on lending rates and volumes to households and private non-financial corporations (PNFC) using the 
following specification:

$$
\left\{\begin{array}{l}
\text { Rrated }_{i t}=\alpha^{r} \text { Irated }_{t}+\beta^{r} \text { Irated }_{t} * \text { crisis }_{t}+\gamma^{r} X_{i} * \text { crisis }_{t}+\delta^{r} \text { crisis }_{t}+\omega_{i}^{r}+\varepsilon_{i t}^{r}, \\
\text { Rvol }_{i t}=\alpha^{v} \text { Irated }_{t}+\beta^{v} \text { Irated }_{t} * \text { crisis }_{t}+\gamma^{v} X_{i} * \text { crisis }_{t}+\delta^{v} \text { crisis }_{t}+\omega_{i}^{v}+\varepsilon_{i t}^{v}, \\
\text { Irated }_{t}=\alpha^{i} \text { Liq }_{t}+\beta^{i} \text { Liq }_{t} * \text { crisis }_{t}+\delta^{i} \text { crisis }_{t}+\varepsilon_{t}^{i} \\
\text { Liq }_{t}=\alpha^{l} \text { pval }_{t}+\beta^{l} \text { pvol }_{t}+\gamma^{l} \text { pval }_{t} * \text { crisis }_{t}+\theta^{l} \text { pvol }_{t} * \text { crisis }_{t}+\delta^{i} \text { crisis }_{t}+\varepsilon_{t}^{l},
\end{array}\right.
$$

where Rrated $_{i t}$ is a rate charged on loans extended to retail borrowers or firms by bank $i$ in month $t$ (households or private non-financial corporations) in basis points deviation from policy rate; rrated $_{t}$ is the secured $(\mathrm{GC})$ rate spread to policy rate in month $t$ in basis points Rvol $_{\text {it }}$ is the growth rate of the stock of loans extended to retail borrowers in month $t$ relative to the previous month; $X_{i}$ is a vector that includes two measures of a bank soundness: (1) the subprime losses over total assets disclosed in the period January 2007 to June 2008; (2) and its retail over interbank deposits ratio reported in June 2007; crisis $_{t}$ is a dummy variable taking value one from August 2007 onwards; Liq $t$ is the aggregate average daily overnight liquidity $(\log ($ billion $£))$ held by UK settlement banks in month $t$; pval $l_{t}$ and pvol $_{t}$ is their average daily payment value (billion $£$ ) and volume (/1000), respectively, both expressed in logarithm.

Each equation also includes quarter fixed effects; two separate dummies for the first and last month of a quarter; and dummies for June, July and August 2007. June 2007 is dummied out because of the uncovered OMO that occurred in the last week of June, and August 2007 accounts for the fact that the BoE interventions in the first month of the crisis were muted. The regression is run on monthly data covering the top five lenders over the sample period January 2007 to May 2008 since from the sixth lender onwards, the volume lent to both households and firms is negligible compared to the top five.

Table 11 reports various descriptive statistics of lending volumes and rates. Few patterns in the data are relevant to point out. First, rates charged to households are on average about 90 basis points higher than rates charged to firms. Second, lending to firms has grown more than three times faster than lending to households in the past two years. Third, large retail banks and low loss banks tend overall to lend at better terms to households but also increased lending by less post-August 2007. This suggests that institutions whose financial condition appears sounder apply tighter lending criteria, i.e., take less risk, both pre- and during the crisis.

The estimation results are reported in Table 12. We find significant evidence in columns (1) to (4) that lenders were prompt at passing increases in the interbank rate onto households and PNFC. For instance, a one basis point rise in the secured interbank spread is associated with 1.3 basis points rise in the floating rate charged to household loans during the crisis. Floating rates tend to be charged on secured mortgage lending and fixed rates on credit card overdrafts and other consumer credit besides mortgages. The average effect on the fixed rates charged on loans to PNFC is of comparable magnitude ${ }^{20}$ Interestingly, before the crisis there is no discernible relationship between the interbank spread and spreads charged on households and PNFC lending. Also, overall the increase in rates observed during the crisis is larger for banks which made larger losses. Retail banks increased their rates more; but they also offered much lower rates pre-crisis so that they had more room for adjustment.

\footnotetext{
${ }^{19}$ We focus on the secured rate because it is the rate the BoE has the objective to keep close to the policy rate. But the results are quite similar if the unsecured (Libor) rate is used instead.

${ }^{20}$ This finding is consistent with descriptive evidence in the BoE Credit Conditions Survey which reported in 2007 Q4 that lenders had revised upwards lending rates on secured credit to households and PNFC.
} 
Columns (5) and (6) suggest that the effect of an increase in the interbank rate on the growth rate of lending to households and PNFC is significantly negative (at all times). On average a 3 basis points increase in interbank rates is associated with a 0.153 percent decline in the growth rate of lending to households. This represents about 10 per cent of a standard deviation decline. The growth rate on lending to firms declines by more and only during the crisis. A 3 basis points rise in interbank rates is associated with about a 0.44 per cent $(24$ per cent of a standard deviation) decline in lending growth to PNFC. We conjecture that a part of the sharper response of corporate borrowing to interbank rates may reflect the ability of businesses, relative to households, to substitute away from bank funding toward market funding when bank borrowing terms rise due to adverse condition of the banking sector 21

All in all, our findings point to the fact as lenders experienced tighter funding conditions in the money market they almost immediately passed on the additional cost to households and small businesses.

\section{Related literature}

Our paper cuts across a number of different strands of literature, in particular, on (i) reasons why firms hoard cash, (ii) the function played by inter-bank markets and the reasons why they may experience stress, (iii) the micro-structure of inter-bank markets in terms of reserves requirements by central banks and the monetary policy, (iv) the transmission of inter-bank market stress to the real economy and as contagion in the financial sector.

The fact that the onset of the sub-prime crisis led banks to hoard liquidity for precaution against funding risk finds parallel in the corporate finance literature on financial constraints. In this literature (see, for example, Almeida, Campello and Weisbach, 2004, and the references therein), when firms cannot pledge a sufficient portion of their future cash flows in capital markets, they attempt to hedge by managing cash. The result is reduced contemporaneous investments. In addition, we also explore the transactional motive for liquidity since banks, especially those in the payments system, settle a large volume of transactions on a daily basis and when the volume becomes large or uncertain, they hold extra liquidity simply to be able to effect these transactions. Indeed, we use the transactional component of cash as an instrument to isolate the effect of the precautionary component.

The rationale for banks to hoard liquidity against aggregate shocks has also been modeled in several papers. Holmstrom and Tirole (1998) argue that in the presence of aggregate liquidity shocks asset sales cannot provide sufficient liquidity for an efficient functioning of markets. Allen and Gale (2000) build a model of co-insurance against uncertain liquidity shocks through bank cross-holdings. Coinsurance works well against idiosyncratic shocks: banks with surpluses provide liquidity to banks with shortages. However the whole liquidity of the banking system is

\footnotetext{
${ }^{21}$ For instance, a document by the Association of Corporate Treasurers, ("Credit crisis corporates - funding and beyond", London, February 2009) argues that capital markets have been seen as replacement funding even for those firms that have traditionally not made use of bonds. Some unrated firms sought their first rating in order to gain access to new sources of funding. The BoE Trends in Lending, available at www.bankofenlgand.co.uk/statistics, published in March 2009 reports that capital issuances were relatively high over the sample period consistent with efforts by some businesses to diversify their funding sources. The BoE Credit Conditions Survey also reported that while household demand for credit continued to rise until 2008 Q3, PNFC sought earlier to reduce their level of debt and cut investment plans. These facts suggest that PNFC have a demand that is more elastic to changes in spreads than households.
} 
bounded by the aggregate liquid assets in the banks' portfolio. Hence while the cross-holdings work perfectly in normal times and help reallocate liquidity across banks, they cannot create additional liquidity. Diamond and Rajan (2001) develop a model where a bank failure can spread to the whole system through a reduction in the common pool of available liquidity. In Allen, Carletti and Gale (2009) liquidity hoarding by banks is driven by an increase in aggregate uncertainty which causes banks to stop using the interbank market to trade with each other. The banks hoard liquidity because they may need it to meet high aggregate demand.

The theory of inter-bank markets generally agrees on its role as being one of liquidity insurance and peer monitoring. The reasons why these markets may fail sometimes or experience severe stress differ across studies. Allen, Carletti and Gale (2008) and Freixas, Martin and Skeie (2008) focus on incompleteness of contracting on liquidity shocks; Bhattacharyya and Gale (1987), Flannery (1996), Bhattacharyya and Fulghieri (1994), Freixas and Jorge (2007), and Heider, Hoerova and Holthausen (2008) focus on asymmetric information and/or counterparty risk and related inefficiencies; finally, Acharya, Gromb and Yorulmazer (2008) focus on issues arising due to market power and strategic behavior of liquidity-surplus banks. While we do not study bilateral inter-bank market data required to investigate strategic behavior, our findings suggest that the stress in inter-markets witnessed during the sub-prime crisis is unlikely to have been due (entirely) to counterparty risk concerns. We find almost identical effects in the Sterling money markets for overnight lending in secured as well as unsecured transactions. In this sense, our findings are more consistent with the inability of banks to hedge at least some funding shocks, aggregate or idiosyncratic.

Our paper also relates to the small literature exploring the microstructure of inter-bank markets. Hamilton (1997) studies the role of bank liquidity in affecting the federal funds rate by employing as an instrument the "errors" in the Federal Reserve forecasts of the effect of its operations on bank reserves. While we control for open market operations in our tests, we rely on the extent of payments activity as an instrument. On this front, our approach is similar to that of Furfine (2000) who calibrates a model as well as empirically demonstrates that daily fed funds rate variability is linked to that of payment flows, and that higher payment flows lead to greater precautionary reserves which put an upward pressure on the funds rate. We take a step further in showing that payment flows are predictable and thus use payment flows as an instrument to isolate the effect of that component of reserves on interest rates that arises as a precaution against unobserved funding risk faced by banks in capital or inter-bank markets.

Ashcraft and Duffie (2007) also provide evidence consistent with precautionary targeting of reserves balances maintained by banks at the Federal Reserve and the role played by "arbitrage" activity of banks using their reserves in ensuring that overconcentration of reserves does not arise in some banks. Ashcraft and Duffie (2007) hint at the possibility that precautionary targeting of reserves by banks, anticipating the heightened risk of hoarding by other banks, can lead to a "gridlock", high interest rates and systemic risk, on days when some large institutions end up with high reserves (by chance or by design). It is possible that precautionary hoardings we identify capture such a phenomenon, but the fact that they increase in our data for weaker banks leads us to conclude that they are potentially also a response to funding needs during adverse conditions 22

\footnotetext{
${ }^{22}$ In contrast to the crisis of 2007-2009, Furfine (2002) finds that the inter-bank markets functioned remarkably well in transferring liquidity in the banking system during the Autumn of 1998 when Long Term Capital Management's problems surfaced.
} 
Our results on transmission of an individual bank's funding risk, and its precautionary hoardings, to other banks and to the real economy do not find a direct parallel in the literature. Nevertheless, this form of contagion is similar in overall spirit to that considered in models of aggregate liquidity shortages such as Freixas and Rochet (1996), Allen and Gale (2000), Freixas, Parigi and Rochet (2000), Diamond and Rajan (2005), and Acharya (2009) wherein banks are reliant on a common pool of liquidity and one bank's adversity reduces the available pool for others due to fire sales of assets, deadweight losses from bad assets, or drawdowns of inter-bank deposits. To the best of our knowledge, a theoretical model, wherein precautionary hoardings of affected banks are explicitly modeled and shown to raise the cost of borrowing for healthier banks giving rise to an interest-rate contagion, does not yet exist.

\section{Conclusion}

By examining the effect of a full-blown financial crisis (starting August 2007) on aggregate liquidity of the banking sector, and its effect on interbank market rates, we uncovered an important precautionary demand channel that caused stress in the Sterling money markets. The economics underlying these effects suggest that the channel was likely to be at work in other countries too, and thus contributed also to the global financial turmoil. Perhaps most interestingly, our results showed that interbank rate volatility can induce volatility in rates to the real economy and also produce a contagion-style systemic risk whereby increase in the precautionary demand for some adversely affected banks leads to rise in borrowing costs for all other banks.

There are several important avenues for future work. Within the aggregate setting, the substitution of liquidity demand between term (3-month) and overnight borrowing seems an intriguing issue to investigate. Further, our study focused on identifying the precautionary motive for liquidity. As such, by showing that effects of liquidity on interbank rates were similar for both secured and unsecured lending, we ruled in favor of the precautionary motive as against the counterparty risk in lending. An additional channel - the "strategic" one - may also be at work. There are two aspects to this channel. One is the strategic behavior in terms of market power of some large players in the interbank markets (e.g., Acharya, Gromb and Yorulmazer, 2008) and on specific days with substantial asymmetry of transaction uncertainty. This would require bilateral analysis of interbank markets and relationships.

The second is the strategic behavior due to adversely affected banks not disclosing their losses early enough and delaying asset sales (Diamond and Rajan, 2009), and safer banks hoarding cash with the motive to acquire these assets at deep discounts in future (Acharya, Shin and Yorulmazer, 2007 and Diamond and Rajan, 2009). It is our prior that this kind of strategic effect was prevalent after the failure of Lehman Brothers when the returns on various kind of assets and strategies rose sky-high and an overall freeze resulted in the global financial system. This too remains a feasible exercise in a bilateral analysis of interbank markets.

\section{References}

[1] Acharya, Viral V. (2009) " A Theory of Systemic Risk and Design of Prudential Bank Regulation," Journal of Financial Stability, forthcoming. 
[2] Acharya, Viral V., D. Gromb and T. Yorulmazer (2008) "Imperfect Competition in the Interbank Market for Liquidity as a Rationale for Central Banking," Working Paper, New York University Stern School of Business.

[3] Acharya, Viral V., Gustavo Suarez and Philipp Schnabl (2009) "Securitization Without Risk Transfer", Working Paper, New York University Stern School of Business.

[4] Acharya, Viral V., Hyun Song Shin and Tanju Yorulmazer (2007) "Crisis Resolution and Bank Liquidity", Working Paper, New York University Stern School of Business.

[5] Allen, F., E. Carletti, and D. Gale (2008) "Interbank Market Liquidity and Central Bank Intervention," Working Paper, New York University.

[6] Allen, F. and D. Gale (2000) "Financial Contagion," Journal of Political Economy, 108(1), pp. 1-33.

[7] Almeida, Heitor, Murillo Campello, and Michael S. Weisbach (2004) "The Cash Flow Sensitivity of Cash," Journal of Finance, 59, 1777-1804.

[8] Ashcraft A. and D. Duffie (2007) "Systemic Dynamics in the Federal Funds Market," American Economic Review, Papers and Proceedings, Vol. 97, 221-225

[9] Bai, J. and P. Perron (1998) "Estimating and Testing Linear Models with Multiple Structural Changes", Econometrica, 66(1), 47-78

[10] Bhattacharya, S. and P. Fulghieri (1994) "Uncertain Liquidity and Interbank Contracting," Economics Letters, 44, 287-294.

[11] Bhattacharya, S. and D. Gale (1987) "Preference Shocks, Liquidity, and Central Bank Policy," in W. Barnett and K. Singleton (eds.) New Approaches to Monetary Economics, Cambridge University Press, Cambridge.

[12] Bester, H. (1985). "Screening vs. Rationing in Credit Markets with Imperfect Information," American Economic Review 75(4), 850-855.

[13] Beaudry, P. and P. Michel (1995) "Competitive Screening in Financial Markets when Borrowers and Firms can Recontract," Review of Economic Studies, 62, 401-423.

[14] Clews, R. (2005) "Implementing Monetary Policy: Reforms to the Bank of England's Operations in the Money Market", Bank of England Quarterly Bulletin, Summer 2005, pages $211-20$.

[15] Diamond, D. and R.G. Rajan (2001), "Liquidity, Risk, Liquidity Creation and Financial Fragility: A Theory of Banking", Journal of Political Economy, 109, 2431-2465.

[16] Diamond, D. and R. G. Rajan (2005) "Liquidity Shortages and Banking Crises," Journal of Finance, 60(2), 615-647.

[17] Diamond, D. and R.G. Rajan (2009), "Fear of Fire Sales and the Credit Freeze," Working Paper, University of Chicago's Booth School of Business. 
[18] Flannery, M. (1996) "Financial Crises, Payment System Problems, and Discount Window Lending," Journal of Money Credit and Banking, 28(2), 804-824.

[19] Freixas, X. and J. Jorge (2007) "The Role of Interbank Markets in Monetary Policy: A Model with Rationing," Working Paper, Universitat Pompeu Fabra.

[20] Freixas, X., A. Martin and D. Skeie (2008) "Bank Liquidity, Interbank Markets, and Monetary Policy," Working Paper, Universitat Pompeu Fabra.

[21] Freixas, X., B. Parigi and J.C. Rochet (2000) "Systematic Risk, Interbank Relations, and Liquidity Provision by the Central Bank," Journal of Money Credit and Banking, 32(3), 611-638.

[22] Furfine, C (1999) 'The Microstructure of the Federal Funds Market', Financial Markets, Institutions and Instruments, 8(5), 24-44.

[23] Furfine C. (2000) "Interbank Payments and the Daily Federal Funds Rate", Journal of Monetary Economics, Vol. 46, 535-553

[24] Furfine C. (2002) "The Interbank Market during a Crisis", European Economic Review, Vol. $46,809-820$

[25] Gale, D. and M. Hellwig (1985) "Incentive-Compatible Debt Contracts: The One-Period Problem," Review of Economics Studies, 52, 647-663.

[26] Hamilton J.D. (1997) "Measuring the Liquidity Effect", American Economic Review, Vol. 87(1), 80-97.

[27] Holmström, B. and J. Tirole (1998) "Private and Public Supply of Liquidity," Journal of Political Economy, 106, 1-40.

[28] Myers, Stewart C., 1977, Determinants of Corporate Borrowing, Journal of Financial Economics, 5(2), 147-175.

[29] Myers, Stewart C., and Nicholas S. Majluf, 1984, Corporate Financing and Investment Decisions When Firms Have Information Investors Do Not Have, Journal of Financial Economics 13, 187-221.

[30] Rochet, J.C. and J. Tirole (1996) "Interbank Lending and Systemic Risk," Journal of Money Credit and Banking, 28(2), 733-762.

[31] Shin H. S. (2009), "Reflections on Northern Rock: The Bank Run that Heralded the Global Financial Crisis", Journal of Economic Perspectives, 23-1, 101-119.

[32] Stiglitz, J. and Weiss, A. (1981). "Credit Rationing in Markets with Imperfect Information," American Economic Review 71, 393-410.

[33] Thornton, D.L. (2001) "Identifying the Liquidity Effect at the Daily Frequency," Federal Reserve Bank of St. Louis Review, 83(4), 59-78. 


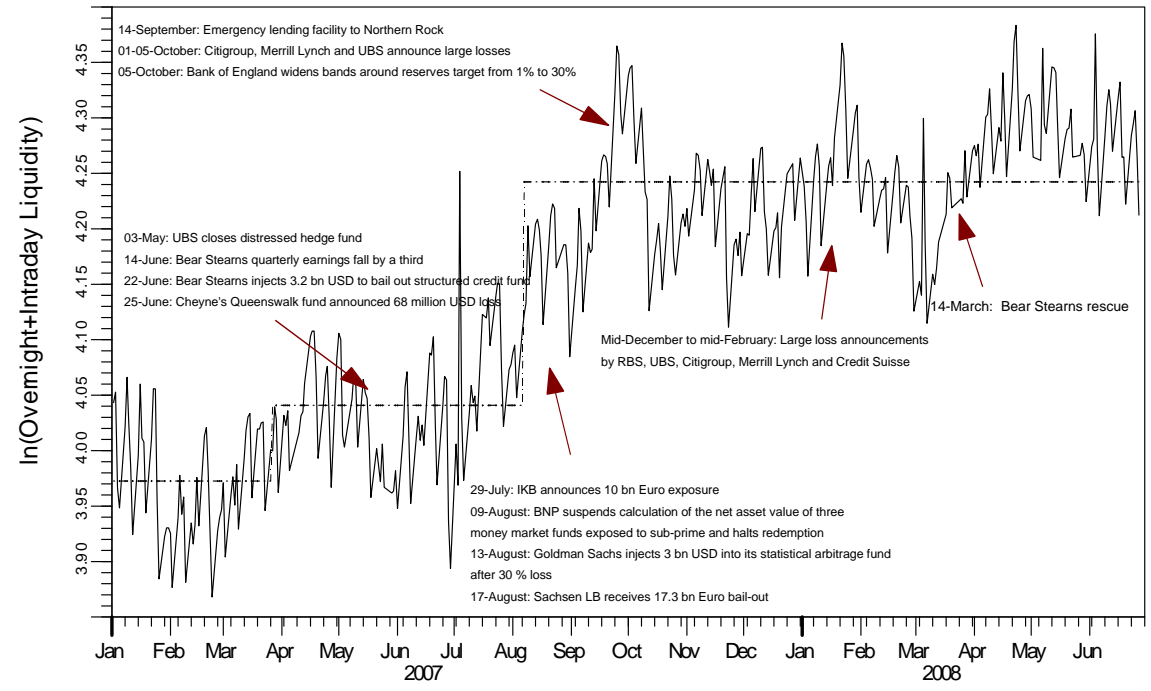

Figure 1: Total liquidity (Overnight + Intraday) held by the banking system

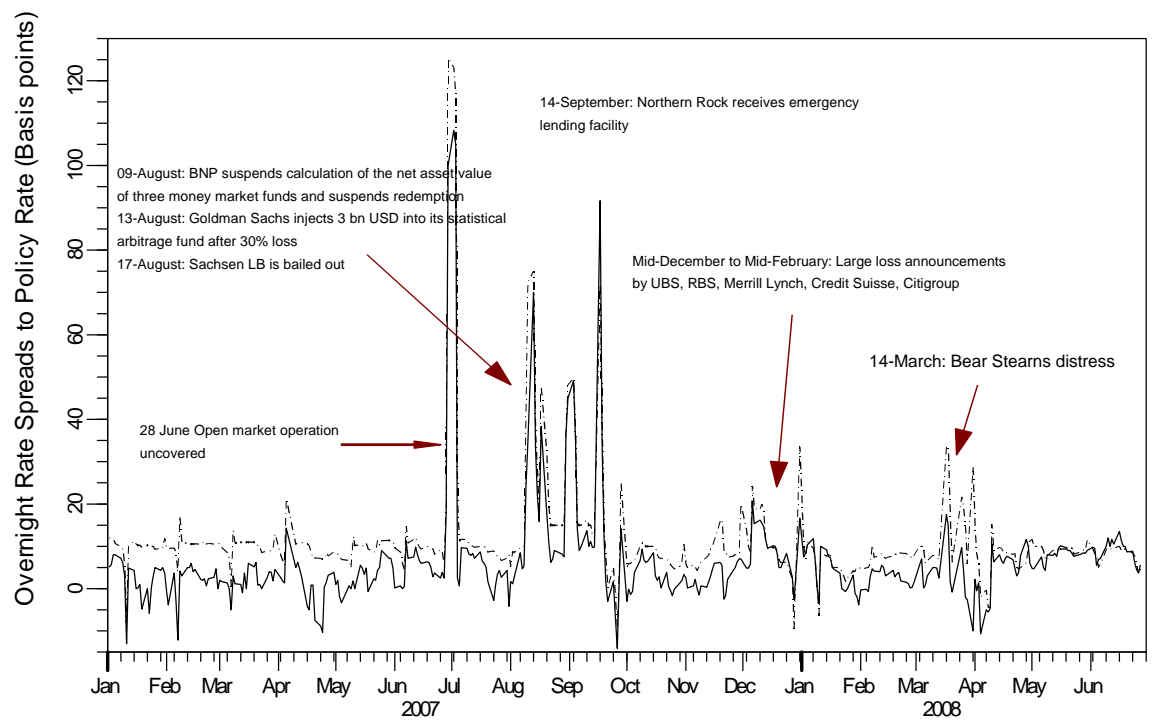

Figure 2: Secured (solid line) and unsecured overnight spreads 


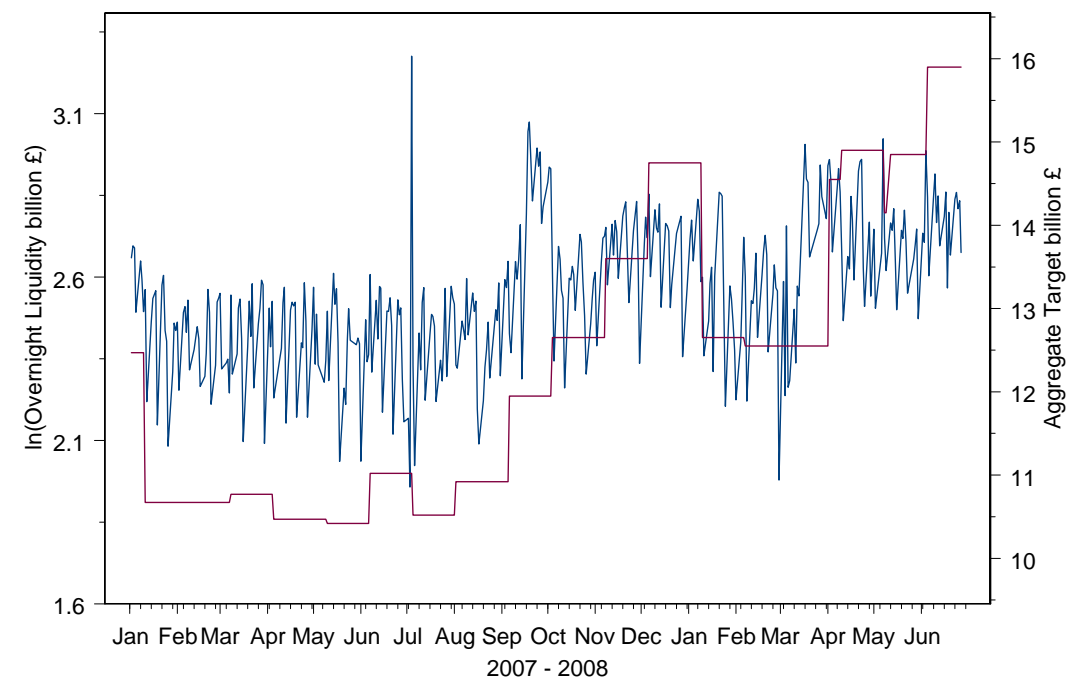

Figure 3: Aggregate Settlement Banks Reserves Target in billion $£$

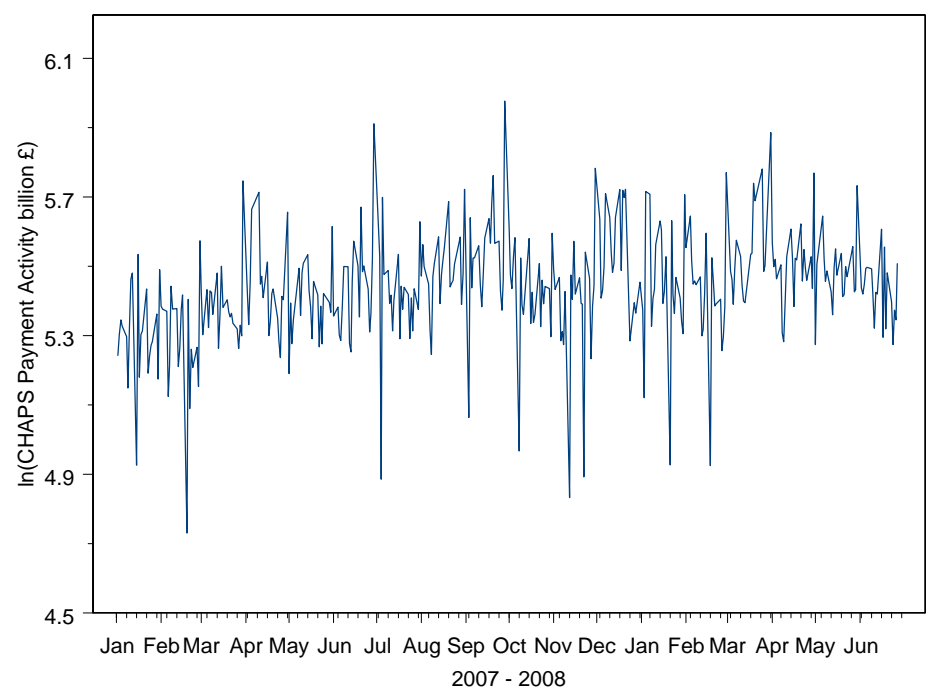

Figure 4: CHAPS payment activity value 


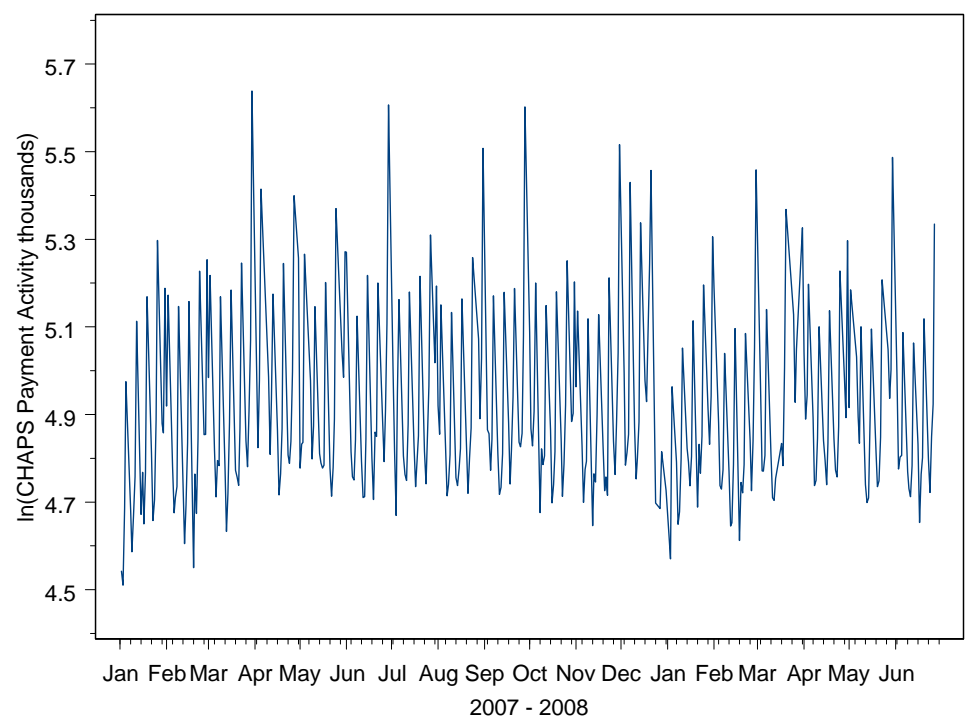

Figure 5: CHAPS payment activity volume

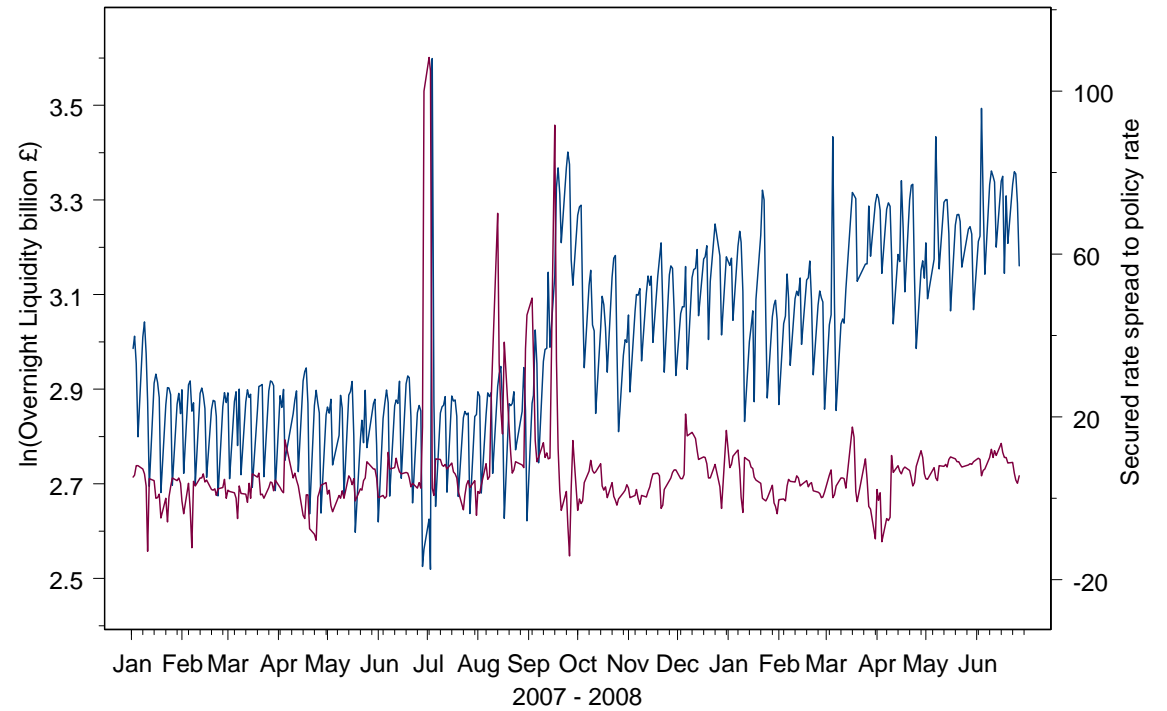

Figure 6: Overnight liquidity and secured rate spread (in basis points) 


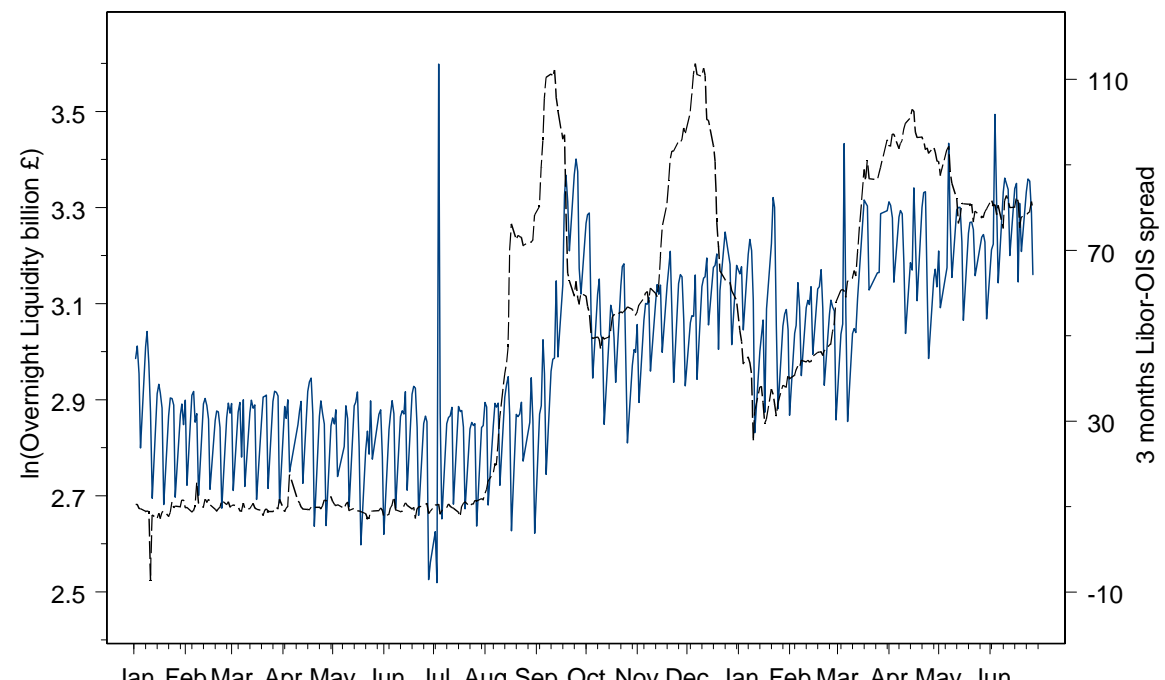

Jan FebMar Apr May Jun Jul Aug Sep Oct Nov Dec Jan Feb Mar Apr May Jun $2007-2008$

Figure 7: Overnight liquidity and 3 months Libor-OIS spread (bps) 
The data are from the Bank of England and are daily for the period 02/01/07 to 30/06/08. First-tier banks are the 10 UK banks that settle their payments and customer payments directly at the central bank. The overnight liquidity is the sum of the reserves accounts balances measured at 5 am each day. The total liquidity includes the overnight and the intraday liquidity. The intraday liquidity is the maximum collateralized intraday-credit that can be obtained from the central bank each day. Payment activity (value and volume) is the sum of all transactions that flow through CHAPS,

the UK large-value payment system ( real-time-gross settlement system operated by the Bank of England). Both the aggregate value and the

aggregate volume of payments are net of interbank loans activity.

Panel 1a- Whole Sample 376 Observations

Variables

In( First Tier Banks Overnight liquidity billion $£$ )

In( First Tier Banks Total liquidity billion $£$ )

In(Payment volume/1000)

\begin{tabular}{lccccccc} 
& Mean & Standard Deviation & Min & Max & 5th percentile & 50th percentile & 95th percentile \\
\hline £) & 2.39 & 0.25 & 1.62 & 3.18 & 1.96 & 2.4 & 2.79 \\
& 4.12 & 0.13 & 3.82 & 4.36 & 3.91 & 4.15 & 4.3 \\
& 4.91 & 0.21 & 4.51 & 5.64 & 4.67 & 4.84 & 5.31 \\
& 5.44 & 0.16 & 4.73 & 5.98 & 5.21 & 5.43 & 5.71 \\
\hline
\end{tabular}

In(Payment value billion $£$ )

Panel 1b- Pre August 9th 2007 (1)

Variables

In( First Tier Banks Overnight liquidity billion $\varepsilon$ )

In( First Tier Banks Total liquidity billion £)

In(Payment volume/1000)

Mean Standard Deviation

Min

$2.23 \quad 0.2$

0.2
0.067

3.98

n(Payment value billion $£$ )

4.91

0.067
0.22
0.15

0.15

$1.62 \quad 3.18$

Max

5th percentile 50 th percentile 95 th percentile

Panel 1c- Post August 9th 2007 (2)

Variables

In( First Tier Banks Overnight liquidity billion $£$ )

$\begin{array}{ll}3.82 & 4.22 \\ 4.51 & 5.64 \\ 4.73 & 5.91\end{array}$

$\begin{array}{llll}3.18 & 1.86 & 2.25 & 2.48 \\ .22 & 3.87 & 3.98 & 4.1 \\ .64 & 4.66 & 4.84 & 5.28\end{array}$

\begin{tabular}{llll}
5.64 & 4.66 & 4.84 & 5.28 \\
5.91 & 5.17 & 5.38 & 5.64 \\
\hline
\end{tabular}

In(Payment volume/1000)

Mean Standard Deviation

25

$5.38-5.64$

In(Payment value billion £)

$\begin{array}{ll}2.5 & 0 \\ 4.22 & 0.0 \\ 4.91 & \\ 5.47 & 0.1\end{array}$

Panel 1d- DIFFERENCE (2)-(1)

Variables

Mn Max 5th percentile 50th percentile 95th percentile

$\begin{array}{llllll}0.22 & 1.89 & 2.96 & 2.1 & 2.51 & 2.82 \\ 0.06 & 4.07 & 4.36 & 4.12 & 4.22 & 4.32\end{array}$

$5.47-0.16$

0.2

$4.57 \quad 5.6$

4.69

$4.84 \quad 5.33$

In( First Tier Banks Overnight liquidity billion $f$ )

In( First Tier Banks Total liquidity billion $£$ )

In(Payment volume/1000)

In(Payment value billion $£$ )

\begin{tabular}{cc} 
Difference & P-value \\
\hline 0.27 & 0 \\
0.24 & 0 \\
0 & 0.67 \\
0.09 & 0 \\
\hline
\end{tabular}




\section{Table 2. Bai-Perron Multiple Level Break Tests on Liquidity Held by First-Tier Banks}

The Bai and Perron (1998) sequential algorithm is used to estimate the timing of (lasting) level shifts in the liquidity series (overnight and total). This method applies an algorithm that searches all possible sets of breaks and determines for each number of breaks the set that produces the maximum goodness-of-fit. The WD max is used to investigate if at least one break is present. If there is evidence for one break the method continues to add breaks until the supLRT(I+1/I) test fails to reject the hypothesis of no additional structural changes at the $5 \%$ level or there is no room for more breaks. We allow for heterogeneous and autocorrelated errors as outlined in Bai and Perron (2003). The trimming parameter is set to 15\%. This implies a minimal window length of about 2 months. The test results are reported in this table together with a timeline of relevant events put together using Bloomberg. See Table 1 for a definition of the intraday and overnight liquidity.

Panel 2a. Dependent Variable: Ln(Overnight Liquidity+Intraday Liquidity)

\section{Break Dates} $95 \%$ Interval Estimates 02/01/2007

27/03/2007 [27/02/07;19/04/07] $3.937^{\star \star \star}$ (0.007) $08 / 08 / 2007$

Sample Starts

$4.213^{\star \star *}$ Bear Stearns provides 3.2 bn dollars financing to bail out structured credit fund

Main Phase

BNP Paribas suspends the calculation of the net asset value of three money market funds exposed to sub-prime

and halts redemption

Goldman Sachs injects $\$ 3 b n$ ( $\$ 2 b n$ of its own capital) into its statistical arbitrage fund

09 August 2007

Sachsen LB receives a $€ 17$.3bn bailout by German state

13 August 2007

Bank of England announces emergency lending facility to Northern Rock

17 August 2007

Bank of England supplies additional reserves to the banking system $+25 \%$ (one week maturity)

14 September 2007

Citigroup says Q3 earnings will fall $60 \%$ on a year ago

01 October 2007

Merrill Lynch announces it will make a loss in Q3 due to a $\$ 5.5$ bn write-down

01 October 2007

Merrill Lynch reports write-downs of $\$ 7.9$ bn on sub-prime mortgages and asset-backed securites

05 October 2007

Morgan Stanley announces a $\$ 3.7 \mathrm{bn}$ loss on sub-prime structured credit

24 October 2007

Rumours of a $\$ 10$ bn write-down by Barclays relating to securities backed by sub-prime mortgages

Note: $\left.{ }^{\star \star \star}\right)$ stands for significant at the 1 per cent level. Standard errors in parenthesis. Liquidity is measured as the sum of reserves accounts held at the central bank. 
Panel 2b. Dependent Variable: Ln(Overnight Liquidity)

\begin{tabular}{|c|c|c|c|c|}
\hline Break Dates & $95 \%$ Interval & Estimates & Timeline of Events (continued) & \\
\hline \multirow[t]{2}{*}{$02 / 01 / 2007$} & & $2.236^{\star \star \star}$ & Bank of America's CEO pre-announces writedowns of \$3bn in Q4. & 13 November 2007 \\
\hline & & $(0.015)$ & Bear Stearns announces an expected write down of $\$ 1.2 \mathrm{bn}$ in Q4 & 14 November 2007 \\
\hline \multirow[t]{2}{*}{$11 / 09 / 2007$} & {$[23 / 08 / 07 ; 18 / 09 / 07]$} & $2.474^{* * *}$ & Freddia Mac announces a Q3 loss of $\$ 2$ bn & 20 November 2007 \\
\hline & & $(0.017)$ & UBS announces further write downs of $\$ 10 \mathrm{bn}$ (dated to end November) & 10 December 2007 \\
\hline \multirow[t]{5}{*}{$13 / 03 / 2008$} & [04/03/08;08/04/08] & $2.629^{* * *}$ & Bank of America announces it may have to record more than its initial $\$ 3.3$ billion losses and write-downs & 12 December 2007 \\
\hline & & $(0.023)$ & Citigroup announces it is to raise at least $\$ 14.5$ billion in new capital & 15 January 2008 \\
\hline & & & Merrill Lynch reports $\$ 10.3$ billion loss & 17 January 2008 \\
\hline & & & Ambac announces Q4 net loss of $\$ 3.225$ billion & 22 January 2008 \\
\hline & & & XL capital Ltd expects Q4 net loss of up to $\$ 1.2$ billion & 23 January 2008 \\
\hline UDmax & SupLRt(2/1) & SupLRt(3/2) & Credit Suisse announces additional $\$ 2.85$ billion losses & 19 February 2008 \\
\hline \multirow[t]{4}{*}{$112.673^{* * *}$} & $17.392^{* * \star}$ & 8.936 & JP Morgan agrees to provide secured lending to Bear Stearns & 14 March 2008 \\
\hline & & & JP Morgan agrees to purchase Bear Stearns for $\$ 2$ per share & 16 March 2008 \\
\hline & & & Fed gives primary dealers effective access to the discount window through a new credit facility & 16 March 2008 \\
\hline & & & HBOS equity price falls sharply on rumours of liquidity problems. HBOS denies any problem. & 19 March 2008 \\
\hline
\end{tabular}

Note: $\left(^{\star \star \star}\right)$ stands for significant at the 1 per cent level. Standard errors in parenthesis. Liquidity is measured as the sum of reserves accounts held at the central bank. 
Table 3. Calendar Effects on the Aggregate level of Payments Activity

This table reports ordinary least squares (OLS) estimates of a regression of the aggregate log payments value and volume on various calendar effects. UK holidays is a dummy taking value one on days just preceeding and following bank holidays; US holidays take value on US holidays and so on so forth. "Quarter 1" takes value one on each day of the last week of the first quarter and so on so forth. Robust standard errors are in parentheses. $\left({ }^{*}\right),\left({ }^{* *}\right),\left({ }^{* * *}\right)$ indicates significance at 10 per cent, 5 per cent and 1 per cent level, respectively.

The results indicate that up to 75 per cent of the variation in payments activity can be explained by few calendar dummies.

\begin{tabular}{lcc}
\cline { 2 - 3 } & OLS (1) & OLS (2) \\
\hline \hline Calendar Dummies & In(Payments Value) & $\ln$ (Payments Volume) \\
\hline \hline
\end{tabular}

\begin{tabular}{|c|c|c|}
\hline United Kingdom Holidays $[-1 ;+1]$ & $\begin{array}{l}0.073^{*} \\
(0.039)\end{array}$ & $\begin{array}{l}0.115^{\star *} \\
(0.048)\end{array}$ \\
\hline United States Holidays [0] & $\begin{array}{l}-0.575^{* * *} \\
(0.032)\end{array}$ & $\begin{array}{c}-0.146^{* * *} \\
(0.024)\end{array}$ \\
\hline First 5 days of the month & $\begin{array}{c}0.002 \\
(0.018)\end{array}$ & $\begin{array}{l}0.044^{* *} \\
(0.018)\end{array}$ \\
\hline Last 5 days of the month & $\begin{array}{l}-0.009 \\
(0.022)\end{array}$ & $\begin{array}{l}0.184^{* * *} \\
(0.021)\end{array}$ \\
\hline Tuesday & $\begin{array}{l}-0.110^{* * *} \\
(0.022)\end{array}$ & $\begin{array}{c}-0.085^{\star * *} \\
(0.017)\end{array}$ \\
\hline Wednesday & $\begin{array}{c}-0.092^{\star \star \star} \\
(0.020)\end{array}$ & $\begin{array}{c}-0.054^{* \star *} \\
(0.018)\end{array}$ \\
\hline Thursday & $\begin{array}{c}-0.059^{* * *} \\
(0.019)\end{array}$ & $\begin{array}{l}0.036^{* *} \\
(0.017)\end{array}$ \\
\hline Friday & $\begin{array}{l}-0.002 \\
(0.021)\end{array}$ & $\begin{array}{c}0.347^{* * *} \\
(0.017)\end{array}$ \\
\hline Quarter 1 & $\begin{array}{c}0.081 \\
(0.064)\end{array}$ & $\begin{array}{c}0.044 \\
(0.052)\end{array}$ \\
\hline Quarter 2 & $\begin{array}{l}0.035 \\
(0.06)\end{array}$ & $\begin{array}{l}-0.019 \\
(0.048)\end{array}$ \\
\hline Quarter 3 & $\begin{array}{c}0.138 \\
(0.107)\end{array}$ & $\begin{array}{l}0.030 \\
(0.074)\end{array}$ \\
\hline Quarter 4 & $\begin{array}{c}-0.111^{* \star *} \\
(0.031)\end{array}$ & $\begin{array}{c}-0.462^{* * *} \\
(0.049)\end{array}$ \\
\hline constant & $\begin{array}{l}5.497^{* * *} \\
(0.015)\end{array}$ & $\begin{array}{c}4.815^{\star * *} \\
(0.012)\end{array}$ \\
\hline $\begin{array}{l}\text { Portmanteau Test for White Noise } \\
\text { at Lag-1 P-value }\end{array}$ & 0.29 & 0.12 \\
\hline R-squared & 0.38 & 0.75 \\
\hline Number of Observ. & 376 & 376 \\
\hline
\end{tabular}

Note: The portmenteau test is run on the residuals from regressions that exclude the constant term.

Mondays are excluded i.e. the model for the test is in calendar time rather than in working days time. 
Table 4. Relationship Between First-Tier (Settlement) Banks Liquidity Holding and Payments Activity

\section{Before and During the Sub-Prime Crisis}

This table reports seemingly-unrelated-least-squares (SURE) estimates of the relationship between UK first-tier banks liquidity (overnight and total) and payment activity

before and during the crisis. See Table 1 for a definition of the overnight and intraday liquidity and payment activity (value and volume).

$\ln ($ Payment value)(t)

In(Payment value)(t)*Break1

$\ln ($ Payment value)(t)*Break2

$\ln ($ Payment value $)(\mathrm{t})^{*}$ Break3

In(Payment volume)(t)

In(Payment volume)(t)*Break 1

In(Payment volume)(t) ${ }^{*}$ Break2

In(Payment volume)(t) ${ }^{\star}$ Break3

Break1

Break2

Break3

Uncovered OMO

\section{Band-Widening}

Higher-Reserves-Target-Ceiling

constant

Maintenance days effects

OMO days effects

R-squared

Number Observ.

\begin{tabular}{cc}
\hline $\ln$ (Overnight Liquidity) & $\ln ($ Total Liquid \\
\hline \hline SURE 1 & SURE 1 \\
\hline$(1)$ & $(2)$ \\
\hline $0.405^{\star \star \star}$ & $0.388^{\star \star \star}$ \\
$(0.079)$ & $(0.049)$ \\
& \\
& \\
& \\
& \\
$-0.484^{\star * *}$ & $-0.301^{\star * *}$ \\
$(0.083)$ & $(0.051)$
\end{tabular}

(0.051)

.049)

$(0.083)$

.

In(Overn

rnight Liquidity)

-0.03
$(0.085)$

0.10
Liquidity) SURE 2

(4)

$0.108^{\star \star *}$

$(0.038)$

$-0.071$

(0.047)

$0.266^{\star \star}$

(0.121)

$-0.001$

$(0.19)$

$-0.304^{* \star}$

$-0.138+4$

$(0.07)$

$-0.138^{\star \star *}$

$(0.03)$

$0.03)$
0.046

(0.033)

$-0.071$

$(0.093)$

0.086

(0.125)

(a)

$0.384^{*}$

$-0.899^{*}$
$(0.554)$
-0.32

$(0.554)$
-0.32

$(0.215)$

(0.843)

Note: $\left.\left(^{*}\right),\left(^{*}\right),{ }^{* \star *}\right)$ stand for significant at the 10 per cent, 5 per cent and 1 per cent level, respectively. Robust standard errors in parentheses.

Uncovered OMO takes value one the last week of June 2007. Band-Widening takes value one in the period 05/10/2007 to 01/05/2008. Higher-Reserves-Target-Ceiling takes value one from 01/05/2008 onwards.

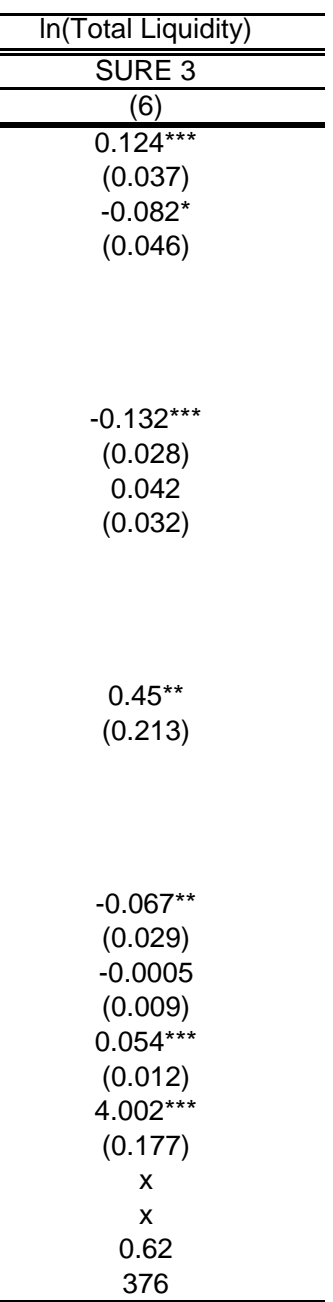

\begin{tabular}{ccc} 
& $(0.564)$ & \\
& -0.596 & \\
& $(0.858)$ & \\
& $-0.210^{\star * *}$ & $-0.067^{* *}$ \\
& $(0.071)$ & $(0.029)$ \\
& $-0.128^{\star * *}$ & -0.0005 \\
& $(0.031)$ & $(0.009)$ \\
& $-0.091^{* *}$ & $0.054^{* \star *}$ \\
$4.11^{\star * *}$ & $(0.04)$ & $(0.012)$ \\
$(0.177)$ & $4.027^{\star * *}$ & $4.002^{* \star *}$ \\
$x$ & $(0.421)$ & $(0.177)$ \\
$x$ & $x$ & $x$ \\
0.81 & $x$ & $x$ \\
376 & 0.13 & 0.62 \\
& 376 & 376 \\
\hline
\end{tabular}

\begin{tabular}{cccccc} 
& & & $(0.04)$ & $(0.012)$ & \\
$2.743^{* * *}$ & $3.505^{* * *}$ & $4.118^{* * *}$ & $4.11^{* * *}$ & $4.027^{* * *}$ & $\left(002^{* * *}\right.$ \\
$(0.4)$ & $(0.247)$ & $(0.415)$ & $(0.177)$ & $x$ & $(0.177)$ \\
$x$ & $x$ & $x$ & $x$ & $x$ & $x$ \\
$x$ & $x$ & $x$ & $x$ & $x$ & $x$ \\
0.24 & 0.17 & 0.58 & 0.81 & 0.13 & 0.62 \\
376 & 376 & 376 & 376 & 376 & 376 \\
\hline
\end{tabular}




\section{Table 5. DESCRIPTIVE STATISTICS: Bank level regressions variables}

See Table 1 for a definition of the overnight liquidity, the intraday liquidity and the payment activity.

\begin{tabular}{|c|c|c|c|c|c|c|c|}
\hline Variables & Mean & Standard Deviation & Min & Max & 5th percentile & 50th percentile & 95th percentile \\
\hline \multicolumn{8}{|l|}{ Used in Table 6} \\
\hline Overnight liquidity (1) & 0.1 & 1.065 & -3.32 & 7.76 & -1.18 & -0.124 & 2.145 \\
\hline Total liquidity (1) & 0.153 & 1.129 & -3.32 & 12.28 & -1.35 & -0.028 & 2.09 \\
\hline Aggregate Payment Value (trillion $£$ ) & 0.263 & 0.038 & 0.133 & 0.425 & 0.210 & 0.259 & 0.335 \\
\hline Aggregate Payment Volume (million) & 0.139 & 0.032 & 0.091 & 0.281 & 0.107 & 0.127 & 0.203 \\
\hline Retail Deposits/Interbank Deposits (2) & 7.13 & 5.27 & 1.39 & 17 & 1.39 & 5.93 & 17 \\
\hline Sub-prime Losses/Total Assets (3) & 0.0009 & 0.0015 & 0 & 0.005 & 0 & 0 & 0.005 \\
\hline Equity Price (4) & 0.058 & 4.66 & -11.25 & 11.7 & -6.6 & 0.038 & 10.13 \\
\hline \multicolumn{8}{|l|}{ Used in Table 10} \\
\hline Own Unsecured Spread to policy rate & & & & & & & \\
\hline (Bps) & 4.428 & 11.208 & -210 & 201 & -5 & 3.286 & 17.424 \\
\hline $\begin{array}{l}\text { Counterparties Unsecured Spread to } \\
\text { policy rate (Bps) }\end{array}$ & 6.076 & 9.938 & -15.616 & 94.743 & -1.342 & 4.419 & 18.082 \\
\hline
\end{tabular}

(1) Normalized by subtracting the mean and dividing by the standard deviation both calculated over the first 12 sample months.

(2) Values reported in June 2007 interim reports

(3) Losses reported from June 2007 to March 2008

(4) Normalized by subtracting the 2006 mean and dividing by the 2006 standard deviation. The source is Bloomberg.

(5) Normalized by subtracting the bank (group) specific sample mean and dividing by the bank (group) specific standard deviation calculated over the first 12 sample months. 


\section{Table 6. Evidence on First-Tier UK Banks' Precautionary Liquidity Reaction during the Sub-Prime Crisis}

This table reports seemigly-unrelated-least-squares estimates of two versions of system (7). The first version in Panel 6a is similar to the one in the text and explains an individual bank demand for liquidity as a function of the aggregate level of payment activity, allowing for a shift in this relationship during the crisis. The second version in Panel $6 \mathrm{~b}$ also allows the precautionary liquidity reaction of banks to aggregate payment shocks to differ between risky and non-risky banks. calendar is a vector of calendar effects (maintenance days and open market operations days). We use two measures of bank risk: (1) the ratio of retail deposits/interbank deposits reported in June 2007 interim reports; (2) the sub-prime losses/total assets ratio, where losses include write-downs and are those reported in the period from June 2007 to June 2008. We also use the variation in the bank equity price relative to 2006 . The deviation in equity price from 2006 is obtained by subtracting the mean and dividing by the standard deviation both measured on 2006 data. Robust standard errors clustered by banks are reported in parentheses. Bank liquidity is normalized by subtracting the mean and dividing by the standard deviation calculated over the first 12 sample months. $\left.\left(^{*}\right),\left(^{* \star}\right),{ }^{* * *}\right)$ stands for statistically significant at the 10 per cent, 5 per cent and 1 per cent level, respectively. The regressions are run on individual banks data covering all first-tier UK banks. Here we only report the results for the overnight liquidity as it is our main focus. 
Panel 6a.

In(Payment value $)(t)$

In(Payment value $)(\mathrm{t})^{\star}$ Break2

In(Payment value)(t)*Break3

In(Payment volume $)(t)$

In(Payment volume $)(\mathrm{t})^{\star}$ Break2

(SubPrime losses/TotalAssets)(i)Break2

(SubPrime losses/TotalAssets)(i)Break2*LowRetail

(SubPrime losses/TotalAssets)(i)Break2*HighRetail

ratio)(i)Break2*LowLoss

ratio)(i)Break2*HighLoss

(Sub-Prime losses/Total assets)(i)*Break3

(Pre Crisis Retail/Interbank deposits ratio)(i)Break3

(SubPrime losses/TotalAssets)(i)Break3*LowRetail

(SubPrime losses/TotalAssets)(i)Break3*HighRetail

(Pre Crisis Retail/Interbank deposits

ratio)(i)Break3*LowLoss

(Pre Crisis Retail/Interbank deposits

ratio)(i)Break3*HighLoss

Equity Price deviation from 2006 (it)

Equity Price deviation from 2006 (it) ${ }^{\star}$ Break2

Equity Price deviation from 2006 (it) ${ }^{\star}$ Break3

Break1

Break2

Break3

Uncovered OMO

Band-Widening

Higher-Reserves-Target-Ceiling

R-squared

Bank + Maintenance days effects

OMO days fixed effects

Number Observ.
In(Payment volume $)(\mathrm{t})^{\star}$ Break3

(Pre Crisis Retail/Interbank deposits ratio)(i)Break2

(Pre Crisis Retail/Interbank deposits

(Pre Crisis Retail/Interbank deposits

\begin{tabular}{|c|c|c|c|c|c|}
\hline (1) & (2) & (3) & (4) & (5) & (6) \\
\hline 0.222 & 0.219 & 0.228 & 0.231 & 0.227 & -0.831 \\
\hline$(0.894)$ & $(0.887)$ & $(0.892)$ & $(0.881)$ & $(0.888)$ & (1.045) \\
\hline 1.753 & 1.754 & 1.764 & $1.804^{*}$ & 1.775 & 1.900 \\
\hline (1.121) & (1.110) & (1.118) & (1.096) & (1.110) & (1.334) \\
\hline $2.025^{\star}$ & $2.030^{*}$ & $1.995^{\star}$ & $1.929^{*}$ & $1.981^{*}$ & $2.585^{\star}$ \\
\hline (1.155) & (1.141) & (1.152) & (1.112) & (1.138) & (1.493) \\
\hline$-2.721^{* * *}$ & $-2.721^{* * *}$ & $-2.719^{* * *}$ & $-2.715^{\star * *}$ & $-2.718^{\star * *}$ & -0.859 \\
\hline (1.011) & (1.004) & (1.008) & (0.999) & (1.005) & (1.177) \\
\hline-1.539 & -1.536 & -1.558 & -1.598 & -1.566 & -1.285 \\
\hline (1.192) & (1.180) & (1.188) & (1.164) & $(1.180)$ & (1.423) \\
\hline-0.182 & -0.189 & -0.148 & -0.072 & -0.131 & -0.583 \\
\hline \multirow[t]{7}{*}{ (1.294) } & $(1.278)$ & (1.290) & (1.245) & $(1.274)$ & (1.662) \\
\hline & $\begin{array}{c}115.654^{\star \star \star} \\
(20.191)\end{array}$ & & & & \\
\hline & & $\begin{array}{c}-0.017^{* * *} \\
(0.006)\end{array}$ & & & \\
\hline & & & $256.421^{\star \star \star *}$ & & \\
\hline & & & $(41.173)$ & & \\
\hline & & & $86.973^{\star \star \star}$ & & \\
\hline & & & $(21.020)$ & & \\
\hline
\end{tabular}

$-0.012^{*}$

(0.006)

$0.037^{* *}$

(0.016)

4.737

(19.811)

$-0.005$

(0.006)

28.176

(39.893)

$-1.184$

(20.367)

$-0.004$

(0.006)

0.0004

(0.016)

$0.089^{\star \star *}$

(0.014)

$-0.078^{* *}$

(0.011)

$-0.001$

(0.008)

\begin{tabular}{cccccc}
$0.159^{* *}$ & $0.159^{* *}$ & $0.161^{\star *}$ & $0.165^{\star *}$ & $0.162^{\star *}$ & $0.260^{\star * *}$ \\
$(0.072)$ & $(0.071)$ & $(0.071)$ & $(0.071)$ & $(0.071)$ & $(0.085)$ \\
0.004 & -0.101 & 0.120 & -0.167 & -0.001 & 0.108 \\
$(0.279)$ & $(0.277)$ & $(0.282)$ & $(0.274)$ & $(0.282)$ & $(0.332)$ \\
$-0.454^{\star}$ & $-0.458^{*}$ & -0.419 & $-0.463^{\star}$ & $-0.430^{*}$ & -0.538 \\
$(0.263)$ & $(0.260)$ & $(0.265)$ & $(0.254)$ & $(0.264)$ & $(0.341)$ \\
-0.237 & -0.237 & -0.238 & -0.238 & -0.238 & -0.154 \\
$(0.176)$ & $(0.175)$ & $(0.175)$ & $(0.174)$ & $(0.175)$ & $(0.203)$ \\
-0.099 & -0.099 & -0.095 & -0.087 & -0.094 & -0.134 \\
$(0.071)$ & $(0.070)$ & $(0.071)$ & $(0.070)$ & $(0.070)$ & $(0.085)$ \\
0.061 & 0.060 & 0.066 & 0.078 & 0.069 & -0.013 \\
$(0.095)$ & $(0.094)$ & $(0.094)$ & $(0.093)$ & $(0.094)$ & $(0.121)$ \\
0.08 & 0.09 & 0.09 & 0.10 & 0.09 & 0.10 \\
$x$ & $x$ & $x$ & $x$ & $x$ & $x$ \\
$x$ & $x$ & $x$ & $x$ & $x$ & $x$ \\
3780 & 3780 & 3780 & 3780 & 3780 & 3780 \\
\hline
\end{tabular}

Note: $\left.\left({ }^{*}\right),{ }^{* *}\right),\left({ }^{* \star *}\right)$ stands for significant at the 10 per cent, 5 per cent and 1 per cent level, respectively. Uncovered OMO takes value one the last week of June 2007. Break1 takes value one from 08/08/07 onwards; Break2 takes value one post 11/09/07; and Break3 takes value one post 13/03/2008. Band-Widening takes value one in the period 05/10/2007 to 01/05/2008. Higher-Reserves-Target-Ceiling takes value one from 01/05/2008 onwards. Column (4) LowRetail takes value one if a bank reports a lower than median retail over interbank deposits ratio in June 2007 and inversely for HighRetail. Column (5) HighLoss takes value one if a bank disclosed higher than median losses as a fraction of total assets and inversely for LowLoss 
Panel 6b

In(Payment value $)(\mathrm{t})^{*}$ HighRisk

In(Payment value $)(\mathrm{t})^{*}$ LowRisk

In(Payment value)(t)*Break2*HighRisk

In(Payment value)(t)*Break2*LowRisk

In(Payment value $)(\mathrm{t})^{\star}$ Break3*HighRisk

In(Payment value)(t)*Break3*LowRisk

In(Payment volume)(t)*HighRisk

In(Payment volume)(t)*LowRisk

In(Payment volume $)(\mathrm{t})^{\star}$ Break2*HighRisk

In(Payment volume $)(\mathrm{t})^{\star}$ Break2*LowRisk

In(Payment volume $)(\mathrm{t})^{\star}$ Break3*HighRisk

In(Payment volume)(t)*Break3LowRisk

Break1

Break2

Break3

Uncovered OMO

Band-Widening

Higher-Reserves-Target-Ceiling

R-squared

Bank fixed effect

Maintenance days effects

OMO days effects

Number Observ.

\begin{tabular}{|c|c|c|}
\hline Risk=Loss & Risk=Retail & Risk=Equity Price \\
\hline$(1)$ & $\overline{(2)}$ & $(4)$ \\
\hline-1.191 & 0.597 & 0.362 \\
\hline (1.162) & (1.016) & (1.495) \\
\hline 1.167 & -0.324 & 0.183 \\
\hline (1.021) & (1.157) & $(0.935)$ \\
\hline $3.645^{\star * *}$ & 1.409 & $3.208^{* *}$ \\
\hline (1.345) & (1.209) & (1.648) \\
\hline 0.192 & $2.388^{*}$ & 1.359 \\
\hline (1.225) & (1.327) & (1.154) \\
\hline 1.367 & 1.379 & 1.670 \\
\hline (1.410) & (1.369) & (1.757) \\
\hline $2.455^{\star}$ & $2.311^{*}$ & $2.167^{*}$ \\
\hline$(1.274)$ & (1.237) & (1.202) \\
\hline 0.205 & -0.384 & -1.457 \\
\hline (1.391) & (1.387) & (1.846) \\
\hline$-4.671^{\star \star *}$ & $-4.271^{\star \star \star}$ & $-3.040^{\star * *}$ \\
\hline (1.194) & (1.191) & (1.072) \\
\hline$-3.837^{* *}$ & -2.823 & -1.463 \\
\hline$(1.841)$ & (1.815) & $(2.574)$ \\
\hline $\begin{array}{c}-0.013 \\
(1.514)\end{array}$ & $\begin{array}{c}-0.772 \\
(1.492)\end{array}$ & $\begin{array}{l}-1.526 \\
(1.315)\end{array}$ \\
\hline 1.409 & 1.733 & 0.410 \\
\hline (2.018) & $(1.960)$ & (2.845) \\
\hline-1.234 & -1.292 & -0.392 \\
\hline (1.655) & (1.607) & (1.441) \\
\hline 0.159 & $0.165^{\star *}$ & $0.156^{\star *}$ \\
\hline$(0.071)$ & $(0.071)$ & $(0.071)$ \\
\hline 0.003 & -0.017 & 0.013 \\
\hline$(0.279)$ & $(0.275)$ & $(0.277)$ \\
\hline$-0.454^{*}$ & $-0.452^{*}$ & $-0.455^{\star}$ \\
\hline$(0.263)$ & $(0.255)$ & $(0.263)$ \\
\hline-0.237 & -0.238 & -0.237 \\
\hline$(0.175)$ & $(0.176)$ & $(0.174)$ \\
\hline-0.098 & -0.089 & -0.104 \\
\hline$(0.071)$ & (0.070) & $(0.070)$ \\
\hline 0.062 & 0.077 & 0.053 \\
\hline$(0.094)$ & $(0.093)$ & $(0.094)$ \\
\hline 0.09 & 0.08 & 0.10 \\
\hline$x$ & $x$ & $x$ \\
\hline$x$ & $x$ & $x$ \\
\hline$x$ & $x$ & $x$ \\
\hline 3780 & 3780 & 3780 \\
\hline
\end{tabular}

Column (1) HighRisk takes value one if a bank disclosed higher than median losses as a fraction of total assets and inversely for LowRisk.

Column (2) HigRisk takes value one if a bank reported a lower than median retail deposit ratio and inversely for LowRisk.

Column (3) HighRisk takes value one if a bank has had lower than average equity price deviations and inversely for LowRisk. 


\section{Table 7. DESCRIPTIVE STATISTICS: Money Markets Rates and Volumes}

Interest rates and volume data are from the British Bankers'Association and the Wholesale Markets Brokers' Association. The 3-month unsecured volume is from the Bank of England; derived using an algorithm similar to Furfine (1998) adjusted to account for an interest payment larger than overnight loans. The secured rate is the Gilt Collateral (GC) rate both for overnight and 3-month. The unsecured overnight rate is the Sterling

Overnight Index Average (SONIA) rate for overnight and the Libor for 3 month.

\section{Panel 7a- Whole Sample 376 Observations}

\begin{tabular}{|c|c|c|c|c|c|c|c|}
\hline Variables & Mean & Standard Deviation & Min & $\operatorname{Max}$ & 5th percentile & 50th percentile & 95th percentile \\
\hline Secured overnight rate & 5.47 & 0.31 & 5.03 & (6.66 & 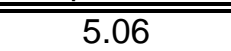 & 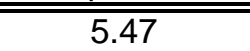 & 5.89 \\
\hline Unsecured overnight rate & 5.52 & 0.32 & 5.04 & 6.75 & 5.08 & 5.52 & 5.94 \\
\hline Secured overnight rate spread to policy rate (Basis points) & 6.25 & 12.65 & -14.17 & 108.33 & -3.88 & 4.5 & 17.5 \\
\hline Unsecured overnight rate spread to policy rate (Bps) & 11.47 & 13.31 & -9.37 & 125.38 & 3.98 & 9.38 & 29.22 \\
\hline In(Secured overnight volume billion $£$ ) & 1.77 & 0.44 & 0.19 & 2.77 & 1.03 & 1.76 & 2.46 \\
\hline In(Unsecured overnight volume billion $£$ ) & 3.12 & 0.16 & 2.58 & 3.59 & 2.85 & 3.12 & 3.39 \\
\hline $\begin{array}{l}3 \text { Months secured rate to overnight index swap spread (Bps) } \\
3 \text { Months unsecured rate to overnight index swap spread }\end{array}$ & -1.32 & 3.45 & -19.9 & 9.87 & -5.03 & -1.63 & 5.28 \\
\hline (Bps) & 46.09 & 34.58 & -7.34 & 113.65 & 8.66 & 45.13 & 100.66 \\
\hline In(unsecured 3 Months volume million $£$ ) & 5.799 & 0.785 & 2.398 & 7.644 & 4.372 & 5.823 & 6.972 \\
\hline \multicolumn{8}{|l|}{ Panel 7b- Pre August 9th 2007 (1) } \\
\hline Variables & Mean & Standard Deviation & Min & Max & 5th percentile & 50th percentile & 95th percentile \\
\hline$\overline{\text { Secured overnight rate }}$ & 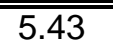 & 0.27 & 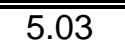 & "6.58 & 5.11 & 5.3 & 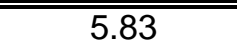 \\
\hline Unsecured overnight rate & 5.5 & 0.27 & 5.06 & 6.75 & 5.16 & 5.36 & 5.85 \\
\hline Secured overnight rate spread to policy rate (Basis points) & 4.82 & 14.78 & -13 & 108.33 & -5 & 3 & 9.72 \\
\hline Unsecured overnight rate spread to policy rate (Bps) & 11.86 & 15.84 & -7.75 & 125.38 & 5.63 & 10 & 15.46 \\
\hline In(Secured overnight volume billion $£$ ) & 1.5 & 0.39 & 0.2 & 2.3 & 0.82 & 1.54 & 2.16 \\
\hline In(Unsecured overnight volume billion $£)$ & 3.04 & 0.16 & 2.58 & 3.59 & 2.79 & 3.05 & 3.34 \\
\hline 3-months secured rate to overnight index swap spread (Bps) & -4.17 & 1.74 & -19.9 & 3.87 & -5.36 & -4.12 & -2.42 \\
\hline 3-months unsecured rate to overnight index swap spread & & & & & & & \\
\hline (Bps) & 10 & 2.41 & -7.34 & 19.88 & 7.62 & 9.78 & 13.33 \\
\hline In(unsecured 3 Months volume million £) & 5.703 & 0.792 & 2.398 & 7.313 & 4.258 & 5.73 & 6.849 \\
\hline
\end{tabular}




\begin{tabular}{|c|c|c|c|c|c|c|c|}
\hline Variables & Mean & Standard Deviation & Min & Max & 5th percentile & 50th percentile & 95th percentile \\
\hline Secured overnight rate & 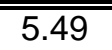 & 0.33 & 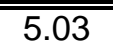 & "6.67 & 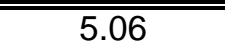 & 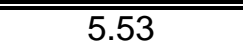 & 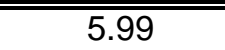 \\
\hline Unsecured overnight rate & 5.55 & 0.35 & 5.04 & 6.5 & 5.08 & 5.55 & 6.1 \\
\hline Secured overnight rate spread to policy rate (Basis points) & 7.23 & 10.89 & -14.17 & 91.67 & -2.93 & 5.97 & 23.67 \\
\hline Unsecured overnight rate spread to policy rate (Bps) & 11.2 & 11.29 & -9.37 & 75 & 1.75 & 8.63 & 35.55 \\
\hline In(Secured overnight volume billion $£)$ & 1.95 & 0.37 & 0.94 & 2.77 & 1.37 & 1.96 & 2.58 \\
\hline In(Unsecured overnight volume billion $£$ ) & 3.17 & 0.14 & 2.84 & 3.55 & 2.94 & 3.17 & 3.4 \\
\hline $\begin{array}{l}3 \text { Months secured rate to overnight index swap spread (Bps) } \\
3 \text { Months unsecured rate to overnight index swap spread }\end{array}$ & 0.64 & 2.92 & -12.83 & 9.87 & -2.67 & 0 & 6.99 \\
\hline (Bps) & 70.97 & 22.27 & 25.04 & 113.65 & 36.43 & 73.04 & 106.24 \\
\hline In(unsecured 3 Months volume million $£$ ) & 5.89 & 0.769 & 2.833 & 7.644 & 4.543 & 5.914 & 7.084 \\
\hline
\end{tabular}

\section{Panel 7d- DIFFERENCE (2)-(1)}

Variables

Difference $\quad$ P-value

Secured overnight rate

0.06

0.004

Unsecured overnight rate

$0.05 \quad 0.13$

Secured overnight rate spread to policy rate (Basis points)

Unsecured overnight rate spread to policy rate (Bps)

$\ln$ (Secured overnight volume billion $£$ )

$2.41 \quad 0.045$

In(Unsecured overnight volume billion $£$ )

$-0.66 \quad 0.61$

$0.45 \quad 0$

$0.13 \quad 0$

3 Months secured rate to overnight index swap spread (Bps)

3 Months unsecured rate to overnight index swap spread

(Bps)

$4.81 \quad 0$

In(unsecured 3 Months volume million £)

60.97

0.187 
Table 8. The Impact of First-Tier Banks Precautionary Liquidity Hoarding on Overnight Money Markets

We report semingly-unrelated-least squares and three-stage-least-squares (3SLS). 3SLS combines 2SLS and SURE. All

spreads are in basis points. The Hansen-Sargan overidentification test is reported. It tests the null hypothesis that the excluded instruments are valid instruments, i.e, uncorrelated with the error term and correctly excluded from the estimated equations. The model is in calendar days time rather than in working days time i.e. Mondays are excluded to avoid the distortion from Friday being both a particularly high payments activity day and the day after the regular weekly open market operation (omo). In other words, the model in calendar days time is preferred because the model in working days time is not well identified; payments activity on day $\mathrm{t}-1$ is a weak instrument for overnight liquidity holding at day $\mathrm{t}$.

Panel 8a: Seemingly Unrelated Least Squares Estimates

\begin{tabular}{|c|c|c|c|c|}
\hline & $\begin{array}{l}\text { Overnight GC- } \\
\text { policy rate } \\
\text { spread } \\
\end{array}$ & $\begin{array}{c}\text { Overnight } \\
\text { Sonia-policy } \\
\text { rate spread }\end{array}$ & $\begin{array}{c}\text { In( Overnight } \\
\text { Secured } \\
\text { Volume) } \\
\end{array}$ & $\begin{array}{c}\text { In(Overnight } \\
\text { Unsecured } \\
\text { Volume) } \\
\end{array}$ \\
\hline & (1) & (2) & (3) & (4) \\
\hline In(Overnight liquidity) & $\begin{array}{c}-20.624^{* * *} \\
(5.351)\end{array}$ & $\begin{array}{c}-18.020^{\star * *} \\
(5.898)\end{array}$ & $\begin{array}{l}-0.128 \\
(0.194)\end{array}$ & $\begin{array}{l}0.138^{*} \\
(0.073)\end{array}$ \\
\hline In(Overnight liquidity)*Break2 & $\begin{array}{c}22.685^{\star * *} \\
(7.046)\end{array}$ & $\begin{array}{c}24.137^{\star * *} \\
(7.766)\end{array}$ & $\begin{array}{l}-0.282 \\
(0.256)\end{array}$ & $\begin{array}{l}-0.092 \\
(0.096)\end{array}$ \\
\hline In(Overnight liquidity)*Break3 & $\begin{array}{c}-13.563 \\
(10.6)\end{array}$ & $\begin{array}{c}-7.900 \\
(11.682)\end{array}$ & $\begin{array}{l}-0.174 \\
(0.385)\end{array}$ & $\begin{array}{l}0.0015 \\
(0.144)\end{array}$ \\
\hline Break2 & $\begin{array}{c}-68.350^{* * *} \\
(18.673)\end{array}$ & $\begin{array}{c}-78.278^{* * *} \\
(20.581)\end{array}$ & $\begin{array}{c}0.813 \\
(0.678)\end{array}$ & $\begin{array}{c}0.174 \\
(0.254)\end{array}$ \\
\hline Break3 & $\begin{array}{c}36.161 \\
(28.963)\end{array}$ & $\begin{array}{c}21.968 \\
(31.922)\end{array}$ & $\begin{array}{c}0.777 \\
(1.051)\end{array}$ & $\begin{array}{c}0.025 \\
(0.393)\end{array}$ \\
\hline Break1 & $\begin{array}{c}14.872^{\star \star \star} \\
(2.391)\end{array}$ & $\begin{array}{c}15.767^{\star \star \star} \\
(2.635)\end{array}$ & $\begin{array}{c}0.277^{\star \star *} \\
(0.087)\end{array}$ & $\begin{array}{c}0.230^{\star \star *} \\
(0.032)\end{array}$ \\
\hline Band-Widening & $\begin{array}{l}-2.375 \\
(2.661)\end{array}$ & $\begin{array}{l}-0.399 \\
(2.933)\end{array}$ & $\begin{array}{c}0.044 \\
(0.097)\end{array}$ & $\begin{array}{c}-0.071^{* *} \\
(0.036)\end{array}$ \\
\hline Higher-Reserves-Target-Ceiling & $\begin{array}{c}2.791 \\
(3.243)\end{array}$ & $\begin{array}{l}-1.251 \\
(3.574)\end{array}$ & $\begin{array}{c}0.081 \\
(0.118)\end{array}$ & $\begin{array}{c}-0.165^{\star * \star} \\
(0.044)\end{array}$ \\
\hline constant & $\begin{array}{c}52.343^{\star * *} \\
(14.794)\end{array}$ & $\begin{array}{c}50.535^{* * *} \\
(16.306)\end{array}$ & $\begin{array}{c}1.790^{* * *} \\
(0.537)\end{array}$ & $\begin{array}{l}2.67^{* * *} \\
(0.201)\end{array}$ \\
\hline Maintenance days effects & $\mathrm{x}$ & $\mathrm{x}$ & $\mathrm{x}$ & $\mathrm{x}$ \\
\hline OMO days effects & $x$ & $\mathrm{x}$ & $\mathrm{x}$ & $x$ \\
\hline Number Observ. & 295 & 295 & 295 & 295 \\
\hline
\end{tabular}

Note: Standard errors are reported in parentheses. $\left(^{*}\right),\left({ }^{\star *}\right),\left({ }^{* \star *}\right)$ stand for significant at the 10 per cent, 5 per cent and 1 per cent level, respectively.

Break1 is a dummy taking value one from August 9th 2007 onwards

Break2 is a dummy taking value one from September 12 th 2007 onwards

Break3 is a dummy taking value one from March 13 th 2008 onwards

Band-Widening takes value one in the period 05/10/2007 to 01/05/2008. Higher-Reserves-Target-Ceiling takes value one from 01/05/2008 onwards. 
Panel 8b: Three-Stage-Least-Squares: Second Stage Estimates

\begin{tabular}{|c|c|c|c|c|c|c|c|c|}
\hline & \multirow{2}{*}{\multicolumn{4}{|c|}{ Overnight GC-policy rate spread }} & \multirow{2}{*}{\multicolumn{4}{|c|}{ Overnight Sonia-policy rate spread }} \\
\hline & & & & & & & & \\
\hline & $(1)$ & $(2)$ & $(3)$ & $(4)$ & $(1)$ & $(2)$ & $(3)$ & $(4)$ \\
\hline In(Overnight liquidity) & $\begin{array}{l}-64.546^{\star *} \\
(25.747)\end{array}$ & $\begin{array}{c}-40.128^{* *} \\
(20.356)\end{array}$ & $\begin{array}{c}-66.002^{* *} \\
(28.503)\end{array}$ & $\begin{array}{c}-43.608^{* *} \\
(22.228)\end{array}$ & $\begin{array}{c}-63.878^{* *} \\
(27.707)\end{array}$ & $\begin{array}{c}-39.7^{\star} \\
(22.418)\end{array}$ & $\begin{array}{l}-65.685^{\star *} \\
(30.602)\end{array}$ & $\begin{array}{c}-43.368^{*} \\
(24.94)\end{array}$ \\
\hline In(Overnight liquidity) ${ }^{\star}$ Break2 & $\begin{array}{c}78.528^{\star * *} \\
(25.298)\end{array}$ & $\begin{array}{l}46.074^{\star *} \\
(19.819)\end{array}$ & $\begin{array}{c}77.661^{* * *} \\
(25.715)\end{array}$ & $\begin{array}{c}44.691^{* *} \\
(19.92)\end{array}$ & $\begin{array}{c}70.017^{\star \star *} \\
(27.223)\end{array}$ & $\begin{array}{l}36.085^{\star} \\
(21.826)\end{array}$ & $\begin{array}{l}68.543^{* *} \\
(27.609)\end{array}$ & $\begin{array}{c}33.656 \\
(22.351)\end{array}$ \\
\hline In(Overnight liquidity) ${ }^{\star}$ Break3 & $\begin{array}{l}-28.411 \\
(41.461)\end{array}$ & $\begin{array}{c}-31.409 \\
(29.719)\end{array}$ & $\begin{array}{c}-0.717 \\
(45.402)\end{array}$ & $\begin{array}{c}-2.701 \\
(32.449)\end{array}$ & $\begin{array}{c}4.585 \\
(44.618)\end{array}$ & $\begin{array}{c}1.217 \\
(32.728)\end{array}$ & $\begin{array}{c}10.414 \\
(48.746)\end{array}$ & $\begin{array}{c}8.763 \\
(36.409)\end{array}$ \\
\hline Break2 & $\begin{array}{c}-207.75^{* * \star} \\
(63.542)\end{array}$ & $\begin{array}{c}-127.777^{\star * *} \\
(49.372)\end{array}$ & $\begin{array}{c}-203.743^{* * *} \\
(67.937)\end{array}$ & $\begin{array}{c}-120.451^{\star *} \\
(51.579)\end{array}$ & $\begin{array}{c}-189.48^{\star \star \star} \\
(63.379)\end{array}$ & $\begin{array}{c}-105.595^{\star *} \\
(54.371)\end{array}$ & $\begin{array}{c}-183.541^{* *} \\
(72.941)\end{array}$ & $\begin{array}{l}-94.897^{*} \\
(57.873)\end{array}$ \\
\hline Break3 & $\begin{array}{c}78.161 \\
(112.534)\end{array}$ & $\begin{array}{c}87.439 \\
(80.695)\end{array}$ & $\begin{array}{c}-0.988 \\
(123.54)\end{array}$ & $\begin{array}{c}5.832 \\
(88.311)\end{array}$ & $\begin{array}{c}-12.746 \\
(121.165)\end{array}$ & $\begin{array}{c}-2.231 \\
(88.866)\end{array}$ & $\begin{array}{c}-28.813 \\
(132.64)\end{array}$ & $\begin{array}{l}-22.701 \\
(99.088)\end{array}$ \\
\hline Break1 & $\begin{array}{c}15.303^{\star * \star} \\
(2.718)\end{array}$ & $\begin{array}{c}16.708^{* * *} \\
(1.949)\end{array}$ & $\begin{array}{c}15.27^{\star * *} \\
(2.743)\end{array}$ & $\begin{array}{c}16.664^{\star * *} \\
(1.961)\end{array}$ & $\begin{array}{c}16.124^{\star \star \star} \\
(2.925)\end{array}$ & $\begin{array}{c}17.662^{\star \star *} \\
(2.147)\end{array}$ & $\begin{array}{c}16.114^{\star * *} \\
(2.948)\end{array}$ & $\begin{array}{c}17.63^{\star \star \star} \\
(2.2)\end{array}$ \\
\hline Uncovered OMO & & $\begin{array}{c}62.382^{* * *} \\
(7.081)\end{array}$ & & $\begin{array}{c}62.02^{\star \star \star} \\
(7.311)\end{array}$ & & $\begin{array}{c}67.706^{\star * *} \\
(7.798)\end{array}$ & & $\begin{array}{c}67.068^{* * *} \\
(8.203)\end{array}$ \\
\hline Band-Widening & & & $\begin{array}{l}-1.631 \\
(6.453)\end{array}$ & $\begin{array}{l}-3.423 \\
(4.53)\end{array}$ & & & $\begin{array}{c}-1.97 \\
(6.928)\end{array}$ & $\begin{array}{l}-4.131 \\
(5.084)\end{array}$ \\
\hline Higher-Reserves-Target-Ceiling & & & $\begin{array}{c}4.742 \\
(5.179)\end{array}$ & $\begin{array}{c}3.036 \\
(3.653)\end{array}$ & & & $\begin{array}{l}-0.969 \\
(5.56)\end{array}$ & $\begin{array}{l}-2.932 \\
(4.099)\end{array}$ \\
\hline constant & $\begin{array}{l}159.183^{*} \\
(64.267)\end{array}$ & $\begin{array}{l}98.987^{\star *} \\
(50.718)\end{array}$ & $\begin{array}{c}162.994^{* \star} \\
(71.572)\end{array}$ & $\begin{array}{c}108.024^{\star *} \\
(55.673)\end{array}$ & $\begin{array}{c}162.931^{* *} \\
(69.16)\end{array}$ & $\begin{array}{l}103.354^{*} \\
(55.854)\end{array}$ & $\begin{array}{c}167.677^{\star *} \\
(76.844)\end{array}$ & $\begin{array}{l}112.971 * \\
(62.469)\end{array}$ \\
\hline Maintenance days effects & $\mathrm{x}$ & $\mathrm{x}$ & $\mathrm{x}$ & $\mathrm{x}$ & $\mathrm{x}$ & $\mathrm{x}$ & $\mathrm{x}$ & $\mathrm{x}$ \\
\hline OMO days effects & $\mathrm{x}$ & $\mathrm{x}$ & $\mathrm{x}$ & $\mathrm{x}$ & $\mathrm{x}$ & $\mathrm{x}$ & $\mathrm{x}$ & $\mathrm{x}$ \\
\hline $\begin{array}{l}\text { Hansen-Sargan Overidentification } \\
\text { statistic= }\end{array}$ & 22.774 & 22.909 & 17.131 & 17.109 & 22.774 & 22.909 & 17.131 & 17.109 \\
\hline$P$-value $=$ & 0.2 & 0.194 & 0.51 & 0.52 & 0.2 & 0.194 & 0.51 & 0.52 \\
\hline Number Observ. & 295 & 295 & 295 & 295 & 295 & 295 & 295 & 295 \\
\hline
\end{tabular}

Note: $\left({ }^{*}\right),\left(^{* *}\right),\left(^{* * *}\right)$ stand for significant at the 10 per cent, 5 per cent and 1 per cent level, respectively. See Panel 6 a for the definition of the Breaks.

Band-Widening takes value one in the period 05/10/2007 to 01/05/2008. Higher-Reserves-Target-Ceiling takes value one from 01/05/2008 onwards.

Uncovered OMO takes value one in the last week of June 2007 
Panel 8b. (continued)

\begin{tabular}{|c|c|c|c|c|c|c|c|c|}
\hline & \multirow{2}{*}{\multicolumn{4}{|c|}{ In(Overnight Secured Volume) }} & \multirow{2}{*}{\multicolumn{4}{|c|}{ In(Overnight Unsecured Volume) }} \\
\hline & & & & & & & & \\
\hline & $(1)$ & $(2)$ & $(3)$ & $(4)$ & $(1)$ & $(2)$ & $(3)$ & $(4)$ \\
\hline In(Overnight liquidity) & $\begin{array}{l}0.411 \\
(0.98)\end{array}$ & $\begin{array}{c}0.373 \\
(1.078)\end{array}$ & $\begin{array}{c}0.517 \\
(1.043)\end{array}$ & $\begin{array}{c}0.483 \\
(1.135)\end{array}$ & $\begin{array}{c}0.343 \\
(0.385)\end{array}$ & $\begin{array}{c}0.432 \\
(0.418)\end{array}$ & $\begin{array}{c}0.307 \\
(0.385)\end{array}$ & $\begin{array}{c}0.406 \\
(0.416)\end{array}$ \\
\hline In(Overnight liquidity)*Break2 & $\begin{array}{c}0.799 \\
(0.963)\end{array}$ & $\begin{array}{c}0.816 \\
(1.049)\end{array}$ & $\begin{array}{c}0.643 \\
(0.941)\end{array}$ & $\begin{array}{c}0.644 \\
(1.017)\end{array}$ & $\begin{array}{c}0.381 \\
(0.378)\end{array}$ & $\begin{array}{c}0.268 \\
(0.407)\end{array}$ & $\begin{array}{c}0.34 \\
(0.348)\end{array}$ & $\begin{array}{c}0.223 \\
(0.373)\end{array}$ \\
\hline In(Overnight liquidity)*Break3 & $\begin{array}{c}-3.495^{\star *} \\
(1.578)\end{array}$ & $\begin{array}{c}-3.498^{\star *} \\
(1.573)\end{array}$ & $\begin{array}{c}-3.413^{\star *} \\
(1.661)\end{array}$ & $\begin{array}{c}-3.402^{\star *} \\
(1.656)\end{array}$ & $\begin{array}{c}0.383 \\
(0.619)\end{array}$ & $\begin{array}{l}0.373 \\
(0.61)\end{array}$ & $\begin{array}{l}-0.023 \\
(0.614)\end{array}$ & $\begin{array}{l}-0.037 \\
(0.608)\end{array}$ \\
\hline Break2 & $\begin{array}{l}-2.073 \\
(2.418)\end{array}$ & $\begin{array}{l}-2.112 \\
(2.614)\end{array}$ & $\begin{array}{l}-2.042 \\
(2.486)\end{array}$ & $\begin{array}{l}-2.034 \\
(2.633)\end{array}$ & $\begin{array}{l}-1.168 \\
(0.949)\end{array}$ & $\begin{array}{c}-0.889 \\
(1.014)\end{array}$ & $\begin{array}{l}-1.079 \\
(0.919)\end{array}$ & $\begin{array}{l}-0.791 \\
(0.966)\end{array}$ \\
\hline Break3 & $\begin{array}{l}9.688^{\star *} \\
(4.284)\end{array}$ & $\begin{array}{l}9.698^{\star *} \\
(4.272)\end{array}$ & $\begin{array}{c}9.523^{* \star} \\
(4.52)\end{array}$ & $\begin{array}{l}9.496^{\star *} \\
(4.508)\end{array}$ & $\begin{array}{l}-1.161 \\
(1.682)\end{array}$ & $\begin{array}{l}-1.131 \\
(1.657)\end{array}$ & $\begin{array}{l}0.029 \\
(1.67)\end{array}$ & $\begin{array}{c}0.068 \\
(1.654)\end{array}$ \\
\hline Break1 & $\begin{array}{c}0.276^{* * *} \\
(0.103)\end{array}$ & $\begin{array}{c}0.277^{\star * *} \\
(0.103)\end{array}$ & $\begin{array}{c}0.278^{* * *} \\
(0.1)\end{array}$ & $\begin{array}{c}0.279^{\star * *} \\
(0.1)\end{array}$ & $\begin{array}{c}0.232^{* * *} \\
(0.041)\end{array}$ & $\begin{array}{c}0.236^{* * *} \\
(0.04)\end{array}$ & $\begin{array}{c}0.232^{\star * *} \\
(0.037)\end{array}$ & $\begin{array}{c}0.237^{* * *} \\
(0.037)\end{array}$ \\
\hline Uncovered OMO & & $\begin{array}{c}0.011 \\
(0.375)\end{array}$ & & $\begin{array}{c}0.032 \\
(0.373)\end{array}$ & & $\begin{array}{c}0.211 \\
(0.145)\end{array}$ & & $\begin{array}{c}0.2 \\
(0.137)\end{array}$ \\
\hline Band-Widening & & & $\begin{array}{l}0.404^{*} \\
(0.236)\end{array}$ & $\begin{array}{l}0.397^{\star} \\
(0.231)\end{array}$ & & & $\begin{array}{c}0.031 \\
(0.087)\end{array}$ & $\begin{array}{c}0.028 \\
(0.085)\end{array}$ \\
\hline Higher-Reserves-Target-Ceiling & & & $\begin{array}{c}0.292 \\
(0.189)\end{array}$ & $\begin{array}{c}0.288 \\
(0.186)\end{array}$ & & & $\begin{array}{l}-0.089 \\
(0.07)\end{array}$ & $\begin{array}{l}-0.093 \\
(0.068)\end{array}$ \\
\hline constant & $\begin{array}{c}0.377 \\
(2.445)\end{array}$ & $\begin{array}{c}0.472 \\
(2.685)\end{array}$ & $\begin{array}{c}0.093 \\
(2.619)\end{array}$ & $\begin{array}{c}0.18 \\
(2.842)\end{array}$ & $\begin{array}{c}2.124^{* *} \\
(0.96)\end{array}$ & $\begin{array}{c}1.905^{\star} \\
(1.041)\end{array}$ & $\begin{array}{l}2.216^{* *} \\
(0.968)\end{array}$ & $\begin{array}{c}1.972^{*} \\
(1.043)\end{array}$ \\
\hline Maintenance days effects & $x$ & $x$ & $x$ & $x$ & $x$ & $x$ & $x$ & $x$ \\
\hline OMO days effects & $x$ & $x$ & $x$ & $x$ & $x$ & $x$ & $x$ & $x$ \\
\hline $\begin{array}{l}\text { Hansen-Sargan Overidentification } \\
\text { statistic= }\end{array}$ & 22.774 & 22.909 & 17.131 & 17.109 & 22.774 & 22.909 & 17.131 & 17.109 \\
\hline$P$-value $=$ & 0.2 & 0.194 & 0.51 & 0.52 & 0.2 & 0.194 & 0.51 & 0.52 \\
\hline Number Observ. & 295 & 295 & 295 & 295 & 295 & 295 & 295 & 295 \\
\hline
\end{tabular}


Panel 8b. (continued)

\begin{tabular}{|c|c|c|c|c|}
\hline & & & & \\
\hline & \multicolumn{4}{|c|}{ In(Overnight Liquidity) } \\
\hline & $(1)$ & $(2)$ & (3) & $(4)$ \\
\hline In(Payment value)(t-1) & $\begin{array}{c}0.132 \\
(0089)\end{array}$ & $\begin{array}{c}0.162^{*} \\
0\end{array}$ & $\begin{array}{c}0.138^{*} \\
0\end{array}$ & $0.162^{* *}$ \\
\hline \multirow[t]{2}{*}{ In(Payment value)(t-1)*Break2 } & 0.143 & 0.126 & 0.068 & 0.055 \\
\hline & $(0.127)$ & $(0.122)$ & $(0.119)$ & $(0.114)$ \\
\hline \multirow[t]{2}{*}{ In(Payment value)(t-1)*Break3 } & -0.009 & 0.012 & 0.169 & 0.182 \\
\hline & $(0.252)$ & $(0.249)$ & $(0.248)$ & $(0.244)$ \\
\hline \multirow[t]{2}{*}{ In(Payment volume)(t-1) } & $-0.310^{\star *}$ & $-0.295^{\star \star \star}$ & $-0.305^{\star *}$ & $-0.282^{\star *}$ \\
\hline & $(0.129)$ & $(0.129)$ & $(0.124)$ & $(0.125)$ \\
\hline \multirow[t]{2}{*}{ In(Payment volume) $(\mathrm{t}-1)^{\star}$ Break2 } & -0.053 & -0.107 & -0.055 & -0.107 \\
\hline & $(0.176)$ & $(0.175)$ & $(0.173)$ & $(0.171)$ \\
\hline \multirow{2}{*}{ In(Payment volume $)(\mathrm{t}-1)^{\star}$ Break3 } & 0.277 & 0.235 & 0.137 & 0.106 \\
\hline & $(0.236)$ & $(0.23)$ & $(0.233)$ & $(0.227)$ \\
\hline \multirow[t]{2}{*}{ Break2 } & -0.317 & 0.04 & 0.249 & 0.572 \\
\hline & $(0.694)$ & $(0.67)$ & $(0.688)$ & $(0.667)$ \\
\hline \multirow[t]{2}{*}{ Break3 } & -1.165 & -1.08 & -1.501 & -1.417 \\
\hline & $(0.934)$ & $(0.907)$ & $(0.985)$ & $(0.952)$ \\
\hline \multirow[t]{2}{*}{ Break1 } & -0.011 & -0.021 & -0.014 & -0.023 \\
\hline & $(0.038)$ & $(0.037)$ & $(0.036)$ & $(0.036)$ \\
\hline \multirow[t]{2}{*}{ Uncovered OMO } & & $-0.248^{\star \star *}$ & & $-0.247^{\star \star \star}$ \\
\hline & & $(0.087)$ & & $(0.084)$ \\
\hline \multirow[t]{2}{*}{ Band-Widening } & & & $-0.168^{\star \star \star}$ & $-0.167^{\star \star *}$ \\
\hline & & & $(0.036)$ & $(0.036)$ \\
\hline \multirow[t]{2}{*}{ Higher-Reserves-Target-Ceiling } & & & $-0.09^{*}$ & $-0.092^{*}$ \\
\hline & & & $(0.049)$ & $(0.049)$ \\
\hline \multirow{2}{*}{ constant } & $3.273^{* * *}$ & $3.046^{\star \star \star}$ & $3.225^{\star * *}$ & $2.991^{* * *}$ \\
\hline & $(0.515)$ & $(0.5)$ & $(0.498)$ & $(0.481)$ \\
\hline Maintenance days effects & $\mathrm{x}$ & $\mathrm{x}$ & $\mathrm{x}$ & $\mathrm{x}$ \\
\hline OMO days effects & $\mathrm{x}$ & $\mathrm{x}$ & $\mathrm{x}$ & $x$ \\
\hline Number Observ. & 295 & 295 & 295 & 295 \\
\hline
\end{tabular}


Table 9. The Impact of First-Tier Banks Precautionary Liquidity Hoarding on Term Money Markets

The outcome variables are the secured and unsecured 3 months rate to OIS spread. In columns (4) to (6) we use the moving average In(overnight liquidity) over a 20 working days windows. In columns (3)-(6) we add the 3-months unsecured volume as an endogeneous variable with data available only for the period $02 / 01 / 07$ to 31/03/2008.

\begin{tabular}{|c|c|c|c|c|c|c|}
\hline & $\begin{array}{c}3 \text { month GC-OIS } \\
\text { spread }\end{array}$ & $\begin{array}{c}3 \text { month Libor-OIS } \\
\text { spread }\end{array}$ & $\begin{array}{c}3 \text { month Unsecured } \\
\text { volume }(a)\end{array}$ & $\begin{array}{c}3 \text { month GC-OIS } \\
\text { spread }\end{array}$ & $\begin{array}{l}3 \text { month Libor- } \\
\text { OIS spread }\end{array}$ & $\begin{array}{c}3 \text { month Unsecured } \\
\text { volume }(\mathrm{a})\end{array}$ \\
\hline & (1) & (2) & (3) & (4) & (5) & $(6)$ \\
\hline \multirow[t]{2}{*}{ In(Overnight liquidity) } & -5.893 & -40.110 & 0.296 & -14.228 & -93.366 & 0.537 \\
\hline & $(6.122)$ & $(45.725)$ & $(2.702)$ & $(10.397)$ & $(80.085)$ & (3.345) \\
\hline \multirow[t]{2}{*}{ In(Overnight liquidity)*Break2 } & 2.468 & 17.395 & 2.361 & $37.295^{\star}$ & $258.730^{*}$ & -6.317 \\
\hline & $(5.487)$ & $(40.978)$ & $(2.079)$ & $(20.048)$ & $(154.425)$ & $(6.450)$ \\
\hline \multirow[t]{2}{*}{ In(Overnight liquidity)Break3 } & -2.163 & 36.219 & 5.460 & -31.769 & -34.338 & 17.107 \\
\hline & (8.938) & $(66.751)$ & $(8.231)$ & $(54762)$ & $(421.811)$ & $(17.617)$ \\
\hline \multirow[t]{2}{*}{ Break2 } & -4.151 & -30.494 & -6.627 & $-93.779^{*}$ & $-647.987^{*}$ & 16.537 \\
\hline & $(14.207)$ & $(106.103)$ & $(5.589)$ & $(51.056)$ & (393.268) & $(16.425)$ \\
\hline \multirow[t]{2}{*}{ Break3 } & 6.253 & -67.600 & -14.768 & 82.629 & 129.336 & -43.106 \\
\hline & $(24.325)$ & $(181.665)$ & $(22.796)$ & $(139.16)$ & $(1071.896)$ & $(44.769)$ \\
\hline \multirow[t]{2}{*}{ Break1 } & $4.993^{* * *}$ & $59.437^{* * *}$ & 0.130 & $4.636^{\star * *}$ & $57.347^{\star * *}$ & 0.139 \\
\hline & $(0.54)$ & $(4.034)$ & $(0.208)$ & $(0.625)$ & $(4.813)$ & $(0.201)$ \\
\hline \multirow[t]{2}{*}{ Uncovered OMO } & $-3.697^{*}$ & -10.707 & -0.029 & -2.909 & -0.348 & 0.018 \\
\hline & $(2.014)$ & $(15.039)$ & $(0.804)$ & $(1.428)$ & $(11.000)$ & $(0.459)$ \\
\hline \multirow[t]{2}{*}{ Band-Widening } & $-3.000^{* *}$ & $-16.653^{*}$ & 0.493 & $-2.909^{* * *}$ & $-21.526^{* * *}$ & -0.037 \\
\hline & $(1.248)$ & $(9.32)$ & $(0.772)$ & $(0.889)$ & $(6.846)$ & $(0.286)$ \\
\hline \multirow[t]{2}{*}{ Higher-Reserves-Target-Ceiling } & $2.926^{\star * *}$ & $-23.539^{* * *}$ & & & & \\
\hline & $(1.006)$ & $(7.515)$ & & & & \\
\hline \multirow[t]{2}{*}{ constant } & 10.898 & 109.364 & 5.272 & 33.100 & 252.352 & 4.610 \\
\hline & $(15.335)$ & (114.528) & $(6.801)$ & (26.399) & (203.338) & (8.493) \\
\hline Maintenance days effects & $x$ & $x$ & $x$ & $x$ & $x$ & $x$ \\
\hline OMO days effects & $x$ & $x$ & $x$ & $x$ & $x$ & $x$ \\
\hline \multicolumn{7}{|l|}{ Hansen-Sargan } \\
\hline Overidentification statistic $=$ & 17.109 & & 3.318 & 6.72 & & \\
\hline$P$-value $=$ & 0.52 & & 0.35 & 0.94 & & \\
\hline Number Observ. & 295 & 295 & 245 & 245 & 245 & 245 \\
\hline
\end{tabular}

Note: see notes in Table 8.

(a) Data available until March 31 st 2008 
Table 10. Bank Level Evidence of Contagion in the Unsecured Money Market

Two-stage-least-squares estimates are reported. The interaction term HighLoss (Lowloss) is a dummy taking value 1 if the bank disclosed a higher (lower) than median sub-prime loss to total assets ratio in the period June 2007 to March 2008. See Table 5 for a definition of the liquidity variables.

\section{Panel 10a}

Own Overnight liquidity

Own Overnight liquidity*Break2

Own Overnight liquidity*Break3

Counterparties Overnight liquidity

Counterparties Overnight liquidity ${ }^{*}$ Break2

Counterparties Overnight liquidity*Break3

Break2

Break3

Break1

Uncovered OMO

Band-Widening

Higher-Reserves-Target-Ceiling

Maintenance days effects and OMO days effects Hansen-Sargan Overidentification statistic=

$\mathrm{P}$-value $=$

Number Observ.

\begin{tabular}{|c|c|c|c|}
\hline \multicolumn{2}{|c|}{ Own borrowing spread } & \multicolumn{2}{|c|}{ Counterparties borrowing spread } \\
\hline$(1)$ & $(2)$ & (3) & (4) \\
\hline 6.854 & -0.434 & 4.434 & -1.728 \\
\hline$(5.781)$ & $(4.718)$ & $(4.190)$ & (3.179) \\
\hline 8.065 & 14.036 & 5.485 & $10.090^{*}$ \\
\hline$(10.715)$ & (8.735) & $(7.555)$ & $(5.733)$ \\
\hline-21.369 & -18.954 & -12.701 & $-14.618^{*}$ \\
\hline$(15.299)$ & (12.496) & (10.587) & (8.073) \\
\hline$-15.561^{* * *}$ & $-6.969^{\star}$ & $-15.464^{* * *}$ & $-5.927^{* *}$ \\
\hline$(4.594)$ & $(4.174)$ & (3.560) & $(3.020)$ \\
\hline $9.910^{*}$ & -1.248 & $10.716^{\star * *}$ & -1.472 \\
\hline$(5.252)$ & $(4.578)$ & $(4.100)$ & (3.301) \\
\hline 9.747 & $13.065^{\star *}$ & $9.053^{*}$ & $13.672^{* * *}$ \\
\hline$(6.477)$ & $(5.226)$ & $(5.559)$ & $(4.197)$ \\
\hline$-14.646^{\star * *}$ & $-12.099^{\star \star *}$ & $-12.908^{* * *}$ & $-10.880^{* * *}$ \\
\hline (4.535) & (3.620) & $(2.281)$ & (2.462) \\
\hline 5.031 & 5.648 & 6.715 & $9.332^{\star *}$ \\
\hline (6.118) & (4.994) & (4.819) & (3.693) \\
\hline $10.999^{* * *}$ & $12.055^{\star * *}$ & $11.101^{* * *}$ & $13.421^{\star * *}$ \\
\hline \multirow[t]{3}{*}{ (1.220) } & (0.995) & $(0.916)$ & $(0.704)$ \\
\hline & $48.914^{\star * *}$ & & $55.471^{* * *}$ \\
\hline & (3.612) & & (2.621) \\
\hline 2.723 & 0.372 & 0.856 & -1.757 \\
\hline (3.212) & (2.575) & (2.173) & (1.628) \\
\hline-4.282 & -8.283 & -7.810 & $-13.856^{* * *}$ \\
\hline (6.723) & $(5.670)$ & (5.623) & (4.285) \\
\hline$x$ & $x$ & $x$ & $x$ \\
\hline 14.63 & 16.38 & 7.76 & 14.67 \\
\hline 0.26 & 0.17 & 0.26 & 0.02 \\
\hline 3145 & 3145 & 3444 & 3444 \\
\hline
\end{tabular}

Note: $\left({ }^{\star}\right),\left(^{\star \star}\right),\left({ }^{\star \star \star}\right)$ stand for significant at the 10 per cent, 5 per cent and 1 per cent level, respectively. Robsut clustered standard errors in parentheses. Band-Widening takes value one in the period 05/10/2007 to 01/05/2008. Higher-Reserves-Target-Ceiling takes value one from 01/05/2008 onwards. Uncovered OMO takes value one in the last week of June 2007.

The CHAPS rate is calculated from the interbank loansdatabase extracted from the Bank of England payments database using the Furfine algorithm. See panel $8 \mathrm{a}$ for the definition of the breaks. 
Panel 10b: Contagion conditional on bank risk

\begin{tabular}{|c|c|c|c|c|}
\hline & (1) & (2) & (3) & (4) \\
\hline Own Overnight liquidity*HighLoss & $\begin{array}{c}1.718 \\
(4.650)\end{array}$ & $\begin{array}{l}-2.626 \\
(4.062)\end{array}$ & $\begin{array}{c}0.395 \\
(4.250)\end{array}$ & $\begin{array}{l}-4.540 \\
(3.522)\end{array}$ \\
\hline Own Overnight liquidity*HighLoss*Break2 & $\begin{array}{c}-4.532 \\
(10.079)\end{array}$ & $\begin{array}{l}2.427 \\
(8.833)\end{array}$ & $\begin{array}{l}5.401 \\
(9.181)\end{array}$ & $\begin{array}{l}12.673^{*} \\
(7.640)\end{array}$ \\
\hline Own Overnight liquidity*HighLoss*Break3 & $\begin{array}{l}11.240 \\
(9.881)\end{array}$ & $\begin{array}{l}10.567 \\
(8.686)\end{array}$ & $\begin{array}{c}1.360 \\
(9.039)\end{array}$ & $\begin{array}{c}1.435 \\
(7.554)\end{array}$ \\
\hline Own Overnight liquidity*LowLoss & $\begin{array}{l}-1.226 \\
(5.573)\end{array}$ & $\begin{array}{l}-9.524^{*} \\
(4.888)\end{array}$ & $\begin{array}{c}2.376 \\
(5.192)\end{array}$ & $\begin{array}{c}-6.084 \\
(4.321)\end{array}$ \\
\hline Own Overnight liquidity*LowLoss*Break2 & $\begin{array}{l}11.919 \\
(7.983)\end{array}$ & $\begin{array}{c}17.850^{* *} \\
(7.005)\end{array}$ & $\begin{array}{c}5.425 \\
(6.507)\end{array}$ & $\begin{array}{l}9.578^{*} \\
(5.409)\end{array}$ \\
\hline Own Overnight liquidity*LowLoss*Break3 & $\begin{array}{c}-16.953^{\star *} \\
(8.609)\end{array}$ & $\begin{array}{c}-14.493^{*} \\
(7.576)\end{array}$ & $\begin{array}{l}-9.968 \\
(7.008)\end{array}$ & $\begin{array}{l}-7.665 \\
(5.873)\end{array}$ \\
\hline Counterparties Overnight liquidity*HighLoss & $\begin{array}{c}-13.091^{* * *} \\
(3.566)\end{array}$ & $\begin{array}{c}-7.425^{\star *} \\
(3.332)\end{array}$ & $\begin{array}{c}-11.285^{\star * *} \\
(3.257)\end{array}$ & $\begin{array}{l}-5.174^{*} \\
(2.884)\end{array}$ \\
\hline Counterparties Overnight liquidity*Break2*HighLoss & $\begin{array}{c}11.677^{\star \star \star} \\
(4.559)\end{array}$ & $\begin{array}{c}2.782 \\
(4.142)\end{array}$ & $\begin{array}{l}7.799^{\star} \\
(4.179)\end{array}$ & $\begin{array}{l}-1.813 \\
(3.588)\end{array}$ \\
\hline Counterparties Overnight liquidity ${ }^{*}$ Break3*HighLoss & $\begin{array}{c}1.432 \\
(5.009)\end{array}$ & $\begin{array}{c}6.016 \\
(4.346)\end{array}$ & $\begin{array}{l}7.857^{*} \\
(4.709)\end{array}$ & $\begin{array}{c}13.151^{* * *} \\
(3.881)\end{array}$ \\
\hline Counterparties Overnight liquidity*LowLoss & $\begin{array}{c}-18.474^{\star * \star} \\
(6.624)\end{array}$ & $\begin{array}{l}-4.840 \\
(6.242)\end{array}$ & $\begin{array}{c}-20.896^{\star * *} \\
(5.863)\end{array}$ & $\begin{array}{l}-6.537 \\
(5.220)\end{array}$ \\
\hline Counterparties Overnight liquidity*Break2*LowLoss & $\begin{array}{c}9.749 \\
(6.887)\end{array}$ & $\begin{array}{l}-5.016 \\
(6.300)\end{array}$ & $\begin{array}{c}15.492^{\star * *} \\
(5.846)\end{array}$ & $\begin{array}{l}-0.540 \\
(5.061)\end{array}$ \\
\hline Counterparties Overnight liquidity*Break3*LowLoss & $\begin{array}{c}11.350^{* *} \\
(5.359)\end{array}$ & $\begin{array}{c}12.902^{\star * *} \\
(4.675)\end{array}$ & $\begin{array}{c}7.091 \\
(4.941)\end{array}$ & $\begin{array}{l}9.613^{* *} \\
(4.095)\end{array}$ \\
\hline Break2 & $\begin{array}{l}-8.317^{\star *} \\
(3.702)\end{array}$ & $\begin{array}{c}-6.662^{* *} \\
(3.198)\end{array}$ & $\begin{array}{c}-11.511^{* * *} \\
(3.315)\end{array}$ & $\begin{array}{c}-9.980^{* * *} \\
(2.735)\end{array}$ \\
\hline Break3 & $\begin{array}{c}0.925 \\
(3.418)\end{array}$ & $\begin{array}{c}1.647 \\
(3.009)\end{array}$ & $\begin{array}{c}3.904 \\
(3.216)\end{array}$ & $\begin{array}{l}5.194^{\star} \\
(2.700)\end{array}$ \\
\hline Break1 & $\begin{array}{c}10.756^{\star * *} \\
(1.018)\end{array}$ & $\begin{array}{c}11.562^{\star * \star} \\
(0.896)\end{array}$ & $\begin{array}{c}12.009^{\star * \star} \\
(0.828)\end{array}$ & $\begin{array}{c}13.522^{* * *} \\
(0.696)\end{array}$ \\
\hline Uncovered OMO & & $\begin{array}{c}47.771^{* * *} \\
(3.084)\end{array}$ & & $\begin{array}{c}54.702^{* * *} \\
(2.588)\end{array}$ \\
\hline Band-Widening & $\begin{array}{l}-2.042 \\
(2.622)\end{array}$ & $\begin{array}{l}-3.424 \\
(2.276)\end{array}$ & $\begin{array}{c}-0.224 \\
(2.255)\end{array}$ & $\begin{array}{l}-2.139 \\
(1.857)\end{array}$ \\
\hline Higher-Reserves-Target-Ceiling & $\begin{array}{l}-5.231 \\
(4.543)\end{array}$ & $\begin{array}{c}-8.423^{\star *} \\
(3.968)\end{array}$ & $\begin{array}{l}-6.642 \\
(4.159)\end{array}$ & $\begin{array}{c}-11.124^{\star \star \star} \\
(3.457)\end{array}$ \\
\hline Maintenance days effects and OMO days effects & $x$ & $x$ & $x$ & $\mathrm{x}$ \\
\hline Hansen-Sargan Overidentification statistic= & 12.73 & 10.13 & 11.55 & 12.41 \\
\hline$P$-value $=$ & 0.39 & 0.60 & 0.48 & 0.41 \\
\hline Number Observ. & 3145 & 3145 & 3444 & 3444 \\
\hline
\end{tabular}

Note: see Panel 10a. HighLoss takes value one if a bank reported higher than median losses as a ratio of total assets (zero otherwise) and inversely for LowLoss. 
Panel 10c: Contagion by large versus small banks

In this table we condition the contagion effect on the size of the bank i.e. whether or not it is one of the top 4 playersin the market in terms of volume.

\section{Own Overnight liquidity*Big}

Own Overnight liquidity ${ }^{\star}$ Big $^{\star}$ Break2

Own Overnight liquidity ${ }^{*}$ Big*Break3

Own Overnight liquidity*Small

Own Overnight liquidity ${ }^{\star}$ Small*Break2

Own Overnight liquidity ${ }^{\star S}$ mall*Break3

Counterparties Overnight liquidity*Big

Counterparties Overnight liquidity ${ }^{\star}$ Break2*Big

Counterparties Overnight liquidityBreak3Big

Counterparties Overnight liquidity*Small

Counterparties Overnight liquidity*Break2*Small

Counterparties Overnight liquidity ${ }^{\star}$ Break3*Small

Break2

Break3

Break1

Band-Widening

Higher-Reserves-Target-Ceiling

Maintenance days effects and OMO days effects Hansen-Sargan Overidentification statistic=

$\mathrm{P}$-value $=$

Number Observ.
Uncovered OMO

\begin{tabular}{|c|c|c|c|}
\hline \multicolumn{2}{|c|}{ Own borrowing spread } & \multicolumn{2}{|c|}{ Counterparties borrowing spread } \\
\hline (1) & (2) & (3) & (4) \\
\hline-5.635 & -2.394 & $-7.115^{\star \star}$ & $-3.442^{*}$ \\
\hline (3.623) & (2.937) & (3.233) & $(2.118)$ \\
\hline 13.687 & 5.459 & $18.323^{* *}$ & $8.902^{*}$ \\
\hline$(9.263)$ & $(7.456)$ & $(8.166)$ & $(5.307)$ \\
\hline-2.082 & 3.389 & -3.945 & 2.127 \\
\hline$(8.846)$ & $(6.831)$ & $(7.523)$ & $(4.794)$ \\
\hline 1.648 & -3.858 & 2.474 & $-3.771^{*}$ \\
\hline$(3.421)$ & $(2.737)$ & (3.101) & $(1.991)$ \\
\hline 6.573 & $10.179^{* *}$ & 2.954 & $5.866^{\star}$ \\
\hline$(6.038)$ & $(4.792)$ & $(4.945)$ & (3.153) \\
\hline$-15.221^{*}$ & $-13.711^{*}$ & -5.851 & -4.534 \\
\hline$(9.284)$ & $(7.386)$ & $(6.642)$ & $(4.264)$ \\
\hline$-9.260^{* * *}$ & $-5.566^{* *}$ & $-8.679^{* * *}$ & $-4.662^{* *}$ \\
\hline (3.401) & (2.813) & $(3.060)$ & (2.042) \\
\hline $8.516^{\star *}$ & 3.092 & $8.214^{\star *}$ & 2.231 \\
\hline (4.145) & (3.356) & (3.662) & $(2.390)$ \\
\hline 1.521 & 2.067 & 1.441 & 2.272 \\
\hline (3.875) & (3.073) & (3.464) & $(2.213)$ \\
\hline$-17.470^{* * *}$ & -5.618 & $-17.731^{* * *}$ & -4.912 \\
\hline (5.162) & (4.545) & $(4.371)$ & (3.107) \\
\hline $13.840^{* *}$ & -0.210 & $16.826^{\star * *}$ & 1.458 \\
\hline (5.522) & $(4.664)$ & $(4.613)$ & (3.122) \\
\hline 7.399 & $9.671^{\star *}$ & 2.640 & $5.543^{\star *}$ \\
\hline (4.896) & (3.850) & (4.317) & $(2.734)$ \\
\hline$-13.194^{* * *}$ & $-10.713^{\star \star *}$ & $-15.401^{* * *}$ & $-12.922^{\star \star \star}$ \\
\hline (3.929) & (3.065) & (3.452) & $(2.177)$ \\
\hline 3.467 & 2.782 & 3.004 & 2.645 \\
\hline (3.383) & (2.681) & (2.935) & (1.878) \\
\hline $10.897^{* * *}$ & $11.970^{* \star *}$ & $11.958^{\star * *}$ & $13.574^{* * *}$ \\
\hline$(0.940)$ & $(0.750)$ & $(0.791)$ & $(0.511)$ \\
\hline & $49.063^{* * *}$ & & $55.640^{\text {*** }}$ \\
\hline & (2.904) & & (2.019) \\
\hline 2.190 & -0.869 & 3.080 & -0.483 \\
\hline$(2.768)$ & (2.159) & (2.329) & $(1.461)$ \\
\hline-3.416 & $-6.299^{*}$ & -1.040 & $-4.857^{* *}$ \\
\hline$(4.151)$ & (3.286) & (3.547) & $(2.264)$ \\
\hline$x$ & $x$ & $x$ & $x$ \\
\hline 10.34 & 14.87 & 12.37 & 44.61 \\
\hline 0.59 & 0.25 & 0.41 & 0.00 \\
\hline 3145 & 3145 & 3444 & 3444 \\
\hline
\end{tabular}

Note: see Panel 10a. Big (Small) is a dummy that takes value 1 if the bank is one (is not one) of the top 4 participants in the market by volume. 


\section{Table 11. Descriptive Statistics Lending to Private Sector: Interest Rates and Volume Growth Rates}

All data (rates and volumes) are from the Bank of England statistics department. The data are monthly for the period January $2007-$ May 2008 and cover the top 5 lenders.

\section{Whole Sample}

85 Observations

\begin{tabular}{|c|c|c|c|c|c|c|c|}
\hline Variables & Mean & Standard Deviation & Min & $\operatorname{Max}$ & 5th percentile & 50th percentile & 95th percentile \\
\hline $\begin{array}{l}\text { Floating rate on new loans to households (1) } \\
\text { Floating rate on new loans to private }\end{array}$ & 68.541 & 36.754 & 9 & 169 & 14.5 & 57 & 141.7 \\
\hline corporations (1) & 160.835 & 48.793 & 48 & 383 & 65 & 164 & 228.4 \\
\hline Fixed rate on new loans to households (1) & 152.141 & 106.94 & -117 & 350 & -12.6 & 133 & 318.7 \\
\hline $\begin{array}{l}\text { Fixed rate on new loans to private corporations } \\
\text { (1) } \\
\text { Growth rate of lending to households \% (2) }\end{array}$ & $\begin{array}{c}147.624 \\
0.392\end{array}$ & $\begin{array}{c}48.914 \\
1.156\end{array}$ & $\begin{array}{l}68.999 \\
-5.375\end{array}$ & $\begin{array}{c}325 \\
2.404\end{array}$ & $\begin{array}{c}72.9 \\
-0.952\end{array}$ & $\begin{array}{c}144 \\
0.513\end{array}$ & $\begin{array}{l}228.7 \\
1.962\end{array}$ \\
\hline $\begin{array}{l}\text { Growth rate of lending to private corporations } \\
\%(2)\end{array}$ & 1.252 & 1.767 & -5.379 & 6.238 & -1.138 & 1.242 & 3.845 \\
\hline
\end{tabular}

(1) Spread to policy rate in basis points

(2) Growth rate relative to previous month

\section{DIFFERENCE (Post August 2007)-(Pre August 2007)}

\section{Variables}

Difference

P-value

Floating rate on new loans to households (1)

Floating rate on new loans to private

corporations (1)

14.37

0

Fixed rate on new loans to households (1)

$\begin{array}{ll}2.39 & 0.77\end{array}$

(1)

Growth rate of lending to households \% (2)

Growth rate of lending to private corporations

$\%(2)$

0.728

0.02

(1) Spread to policy rate in basis points

(2) Growth rate relative to previous month 
Difference Tables by Risk Factor For Rates

\begin{tabular}{|c|c|c|c|c|c|c|}
\hline & \multirow{2}{*}{\multicolumn{3}{|c|}{ Household Floating rate }} & \multirow{2}{*}{\multicolumn{3}{|c|}{ Private Corporations Floating rate }} \\
\hline & & & & & & \\
\hline & $(1)$ & $(2)$ & & $(1)$ & $(2)$ & \\
\hline & Pre August 9th & Post August 9th & $\begin{array}{c}\text { Difference (2)-(1) }=0 \\
(\text { Test P-value) }\end{array}$ & Pre August 9th & Post August 9th & $\begin{array}{c}\text { Difference }(2)-(1)=0 \\
(\text { Test P-value) }\end{array}$ \\
\hline High Retail/Interbank deposit Ratio & 47.857 & 62.733 & $\begin{array}{l}14.876 \\
(0.01)\end{array}$ & 138.952 & 155.5 & $\begin{array}{c}16.548 \\
(0.13)\end{array}$ \\
\hline Low Retail/Interbank deposit Ratio & 78.429 & 92.05 & $\begin{array}{r}13.621 \\
(0.05)\end{array}$ & 190.143 & 171.3 & $\begin{array}{c}-18.843 \\
(0.04)\end{array}$ \\
\hline High Loss/Total Assets Ratio & 71.048 & 95.733 & $\begin{array}{l}24.685 \\
(0)\end{array}$ & 170.429 & 174.167 & $\begin{array}{l}3.738 \\
(0.66)\end{array}$ \\
\hline Low Loss/Total Assets Ratio & 43.643 & 42.55 & $\begin{array}{l}-1.093 \\
(0.78)\end{array}$ & 142.929 & 143.3 & $\begin{array}{l}0.371 \\
(0.98)\end{array}$ \\
\hline te: High means higher than or equal to median an & wer than median & & & & & \\
\hline & & Household Fixed 1 & & Priv & ate Corporations F & ixed rate \\
\hline & $(1)$ & $(2)$ & & $(1)$ & (2) & \\
\hline & Pre August 9th & Post August 9th & $\begin{array}{c}\text { Difference (2)-(1) }=0 \\
(\text { Test P-value) }\end{array}$ & Pre August 9th & Post August 9th & $\begin{array}{c}\text { Difference }(2)-(1)=0 \\
(\text { Test P-value) }\end{array}$ \\
\hline High Retail/Interbank deposit Ratio & 50.571 & 170.800 & $\begin{array}{c}120.23 \\
(0)\end{array}$ & 131.428 & 151.095 & $\begin{array}{l}19.67 \\
(0.01)\end{array}$ \\
\hline Low Retail/Interbank deposit Ratio & 181.928 & 209.950 & $\begin{array}{l}28.02 \\
(0.17)\end{array}$ & 160.286 & 130.786 & $\begin{array}{r}-29.50 \\
(0.01)\end{array}$ \\
\hline High Loss/Total Assets Ratio & 115.952 & 202.533 & $\begin{array}{c}86.58 \\
(0)\end{array}$ & 162.433 & 149.467 & $\begin{array}{r}-12.97 \\
(0.09)\end{array}$ \\
\hline Low Loss/Total Assets Ratio & 83.857 & 162.350 & $\begin{array}{l}78.49 \\
(0)\end{array}$ & 133.550 & 153.00 & $\begin{array}{l}19.45 \\
(0.26)\end{array}$ \\
\hline
\end{tabular}

Note: High means higher than or equal to median and Low lower than median 
Difference Tables by Risk Factor For Growth of Lending Volumes

\begin{tabular}{|c|c|c|c|c|c|c|}
\hline & \multicolumn{3}{|c|}{ Household lending growth rate } & \multicolumn{3}{|c|}{ Private Corporations lending growth rate } \\
\hline & $(1)$ & $(2)$ & & $(1)$ & $(2)$ & \\
\hline & Pre August 9th & Post August 9th & $\begin{array}{c}\text { Difference (2)-(1) }=0 \\
(\text { Test P-value) }\end{array}$ & Pre August 9th & Post August 9th & $\begin{array}{c}\text { Difference (2)-(1) }=0 \\
(\text { Test P-value) }\end{array}$ \\
\hline High Retail/Interbank deposit Ratio & -0.003 & 0.257 & $\begin{array}{c}0.26 \\
(0.48)\end{array}$ & 0.909 & 1.641 & $\begin{array}{l}0.732 \\
(0.28)\end{array}$ \\
\hline Low Retail/Interbank deposit Ratio & 0.16 & 1.091 & $\begin{array}{c}0.931 \\
(0)\end{array}$ & 0.629 & 1.351 & $\begin{array}{l}0.722 \\
(0.04)\end{array}$ \\
\hline High Loss/Total Assets Ratio & 0.056 & 0.711 & $\begin{array}{c}0.655 \\
(0)\end{array}$ & 0.248 & 1.335 & $\begin{array}{l}1.087 \\
(0.08)\end{array}$ \\
\hline Low Loss/Total Assets Ratio & 0.071 & 0.409 & $\begin{array}{l}0.338 \\
(0.55)\end{array}$ & 1.621 & 1.81 & $\begin{array}{l}0.189 \\
(0.69)\end{array}$ \\
\hline
\end{tabular}

Note: High means higher than or equal to median and Low lower than median 
Table 12. The Transmission of Money Market Volatility on Real Economic Activities

In this table we report estimates of the effect of higher volatility in interbank markets on lending volume to households and non

financial corporations and rates as specified in system (8) and using 3SLS. The growth rate of the stock of loans extended to retail borrowers is calculated relative to the previous month; crisis is a dummy variable taking value one from August 2007

onwards. The model is estimated using three-stage-least squares on monthly data covering the top five banks in the period January 2007 to May-June 2008.

\begin{tabular}{|c|c|c|c|c|c|}
\hline \multicolumn{2}{|c|}{ Rates spread to policy rate } & \multicolumn{2}{|c|}{ Rates spread to policy rate } & \multicolumn{2}{|c|}{ Lending volume growth rate $\%$} \\
\hline \multicolumn{2}{|c|}{ Floating rate } & \multicolumn{2}{|c|}{ Fixed rate } & & \\
\hline Households & Private Corporations & Households & Private Corporations & Households & Private Corporations \\
\hline-0.1 & 0.781 & 1.131 & $1.491^{* *}$ & $-0.053^{*}$ & 0.027 \\
\hline$(0.47)$ & $(0.949)$ & $(1.180)$ & $(0.723)$ & $(0.031)$ & $(0.049)$ \\
\hline $\begin{array}{l}1.305^{\star *} \\
(0.618)\end{array}$ & $\begin{array}{c}0.615 \\
(1.246)\end{array}$ & $\begin{array}{l}-0.495 \\
(1.550)\end{array}$ & $\begin{array}{l}-0.102 \\
(0.950)\end{array}$ & $\begin{array}{l}0.016 \\
(0.04)\end{array}$ & $\begin{array}{c}-0.146^{* *} \\
(0.065)\end{array}$ \\
\hline $\begin{array}{c}2.861 \\
(1.862)\end{array}$ & $\begin{array}{l}8.098^{* *} \\
(3.770)\end{array}$ & $\begin{array}{c}14.199^{* * *} \\
(4.660)\end{array}$ & $\begin{array}{c}17.392^{* \star \star} \\
(2.875)\end{array}$ & $\begin{array}{l}-0.140 \\
(0.119)\end{array}$ & $\begin{array}{c}0.125 \\
(0.190)\end{array}$ \\
\hline $9.740^{\text {***}}$ & 5.099 & $12.462^{* *}$ & $-6.989 * *$ & 0.010 & 0.185 \\
\hline$(2.2)$ & $(4.456)$ & $(5.508)$ & $(3.400)$ & $(0.141)$ & $(0.225)$ \\
\hline-14.313 & $-50.993^{* * *}$ & $39.105^{*}$ & $-63.726^{\star * \star}$ & $1.139^{* *}$ & 0.378 \\
\hline$(8.931)$ & (18.052) & $(22.364)$ & $(13.763)$ & $(0.574)$ & $(0.921)$ \\
\hline $35.266^{\star * *}$ & $120.177^{\star \star \star}$ & -10.694 & $166.088^{* \star *}$ & 0.600 & 0.437 \\
\hline$(11.185)$ & $(23.447)$ & $(28.031)$ & $(17.191)$ & $(0.502)$ & $(1.211)$ \\
\hline \multicolumn{6}{|l|}{30.913} \\
\hline \multicolumn{6}{|l|}{0.321} \\
\hline 0.84 & 0.62 & 0.87 & 0.79 & 0.28 & 0.21 \\
\hline $\mathrm{x}$ & $x$ & $x$ & $x$ & $x$ & $x$ \\
\hline$x$ & $x$ & $x$ & $x$ & $x$ & $x$ \\
\hline 80 & 80 & 80 & 80 & 80 & 80 \\
\hline
\end{tabular}

Interbank rate spread to policy rate $(\mathrm{t})$

Interbank rate spread to policy rate $(\mathrm{t})^{\star}$ crisis

(Pre crisis Retail deposits/Interbank deposits)(i)* crisis(t)

(Sub-Prime losses/Total

assets) $(\mathrm{i})^{*} \operatorname{crisis}(\mathrm{t})^{*} 1000$

$\operatorname{crisis}(\mathrm{t})(\mathrm{a})$

constant

Hansen-Sargan Overidentification

statistic $=$

$P$-value $=$

R-squared

Bank fixed effects

Seasonal Dummies

Nbr. Observations

Note: Standard errors are reported in parentheses. $\left({ }^{\star}\right),\left({ }^{* \star}\right),\left({ }^{* \star \star}\right)$ stand for statistically significant at the 10 per cent, 5 per cent and 1 per cent level, respectively

Seasonal dummies include quarter fixed effects; two dummies for the first month and the last month of a quarter; dummies for the months of June, July and August 2007.

(a) crisis is a post August 8th 2007 dummy variable. 